\title{
Domestic Violence Asylum and the Perpetuation of the Victimization Narrative
}

\author{
NATALIE NANASI* \\ TABLE OF CONTENTS
}

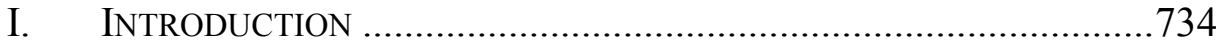

II. BATTERED WOMAN SYNDROME AND LEARNED

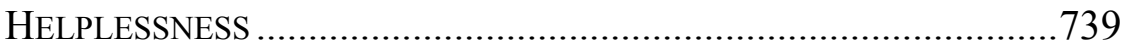

A. The Battered Woman ..........................................................739

B. Critiques........................................................................... 741

III. A BRIEF History OF DOMESTIC VIOLENCE ASYLUM IN THE UNITED STATES ............................................................ 743

A. Asylum and the Law of Particular Social Group ..................743

B. Matter of Kasinga ............................................................746

C. Matter of R-A- .............................................................. 746

D. Matter of L-R-............................................................749

E. Matter of A-R-C-G- .....................................................751

IV. The Problematic AsPeCts of Asylum LAW's USE OF

PARTICULAR SOCIAL GROUPS THAT FURTHER THE

HELPLESS BATTERED WOMAN NARRATIVE...............................752

A. The Power of Narrative and Danger of Stock Stories ..........752

B. The Consequences of Failure to Conform to the Prevailing Victim Narrative............................................ 754

C. Lawyering and Feminist Critiques .....................................758

1. Challenges for Client-Centered and Ethical Advocacy ...............................................................758

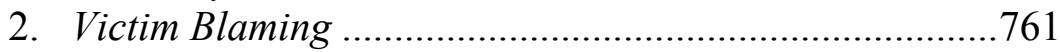

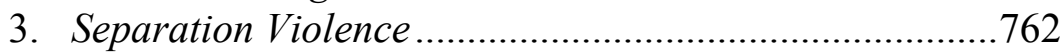

D. The "Worthiness" Problem ..................................................764

V. PROPOSED FIXES ................................................................ 765

A. Issuance of a Final Rule Governing Domestic

Violence Asylum Claims ....

B. Advancing Alternative, Non-Essentializing, Particular

* Assistant Professor and Director, Judge Elmo B. Hunter Legal Center for Victims of Crimes Against Women, SMU Dedman School of Law. The author wishes to thank Elizabeth Keyes, Amy Myers, Danielle Pelfrey Duryea, Courtney Cross, and David Koplow for their helpful feedback, as well as the attendees of the University of Baltimore's 9th Annual Feminist Legal Theory Conference and the University of Akron Center for Constitutional Law's U.S. Feminist Judgments Project Conference for their insightful comments and questions. Gratitude also goes to Rachel Marshall for her invaluable research assistance and the students of the Ohio State Law Journal for their capable and professional editing. 
Social Groups .766

1. Women as a Particular Social Group.....

2. Women Who Resist Domestic Violence but Are Unable to Leave Their Relationship

3. Women Who Assert Independence from Abusive Partners or Women Who Challenge Male Domination

4. Women Who are Married to (or in Relationships with) Abusive Men

5. Women Who Have Fled an Abusive Relationship

VI. CONCLUSION

\section{INTRODUCTION}

Ana ${ }^{1}$ met her abuser when she was only nineteen years old. Doting and attentive in the first few months, his attention soon became overwhelming. He was angry and jealous whenever Ana spent time with her friends and raged when she danced with male cousins at family get-togethers. A year into the relationship, Ana became pregnant and the physical violence began. Unable to tolerate any deviation from the way he expected "his woman" to behave, he lashed out brutally at any misstep. The pushes and shoves whenever she "disappointed" him escalated to regular beatings, kicks, lashes, and strangling. His machete was always at his side, even in the middle of the night, and he threatened that Ana would feel the weight of its blade if she ever disobeyed or left him.

One night, after claiming that the rice Ana made him for dinner was flavorless, he rubbed spices in her face and eyes and slammed her head against the kitchen counter. Desperate to free herself from his hold, she grasped for a nearby pan; the force of the metal against his shoulder startled him and gave Ana a few critical moments to lock herself in her room for safety. The next morning, he tousled her hair and said he hoped to see such fire in the bedroom soon.

Ana was ashamed of the gashes and bruises that covered her arms and legs, so she spent much of her life inside the small home she shared with her abuser. The hours cleaning and playing with her baby were relatively peaceful, as her husband was often out drinking with his military buddies, many of whom now worked odd hours at the local police station. She knew that things would be at their worst when he came home smelling of whiskey, so as the years passed, Ana learned his patterns and deliberately instigated his attacks. She would stand up to him or antagonize him (including through physical

${ }^{1}$ Ana is a fictional character, but her story is an amalgamation of client stories I have been entrusted with the opportunity to hear in my time as a lawyer representing immigrant survivors of domestic violence both in my work as a clinical teacher and as an attorney at the nonprofit Tahirih Justice Center. 
violence of her own) when he was sober, or when their child was less likely to be at home to witness her father's violence. Ana also began to hide objects strategically around the house - nail files, bookends, canes - so that she could use them to fend off the most extreme abuse. She usually hit only hard enough to stun, but one night she was so angry that she knocked him unconscious with a potted plant.

Ana sank into a deep depression but did not want to bother her mother, who had faced similar violence at the hands of her own husband, with her problems. Her sisters, busy with their families, advised her to do more to keep her man happy. Ana was alone and penniless (because she had never been permitted to work), a fact her husband often reminded her of. "Who else would love you?" he mocked. He dared her to leave him, assuring her that if she did, she would do so alone, as he would never allow their child to be raised without his influence. Seeing no other option, Ana decided to stay.

Then, one day, her husband disappeared. He came back a week later smelling of alcohol and perfume and told her that he no longer wanted to see her "fat and disgusting" face - he had booked her a ticket to the United States where she would stay with his brother's family. Ana seized the opportunity for freedom and safety; she made the difficult but strategic calculation that her daughter would be safer with her mother until Ana was settled in the United States, and boarded the plane.

In the United States, she felt free and safe for the first time in her life. As she began making plans to remain permanently, a letter from her husband arrived. He demanded that she return to him immediately and told her that if she was not home within the month, he would dispatch his cousin, a known gang member, who would give her a "permanent home" in a grave in the United States.

Ana's story is undoubtedly a tragic one, but would the persecution she endured make her eligible for asylum protection in the United States? If her story is told in its current form, the answer is no. Unless the aspects of Ana's narrative that show her to be a strong, rational, and powerful actor are omitted, she would likely fail in her attempts to obtain refuge and achieve safety in this country.

Although likely not contemplated as a basis for protection by the drafters of the 1951 Refugee Convention, ${ }^{2}$ which included the refugee definition that was later codified in U.S. law, ${ }^{3}$ domestic violence has become an accepted ground for seeking asylum in the United States. However, the road has been neither clear nor easy. The seminal case of Matter of $R$ - $A$-was the source of

${ }^{2}$ See Convention Relating to the Status of Refugees art. 1, opened for signature July 28, 1951, 19 U.S.T. 6623, 189 U.N.T.S. 150 (entered into force Apr. 22, 1954) (including only those with a "well-founded fear of being persecuted for reasons of race, religion, nationality, [or] membership of a particular social group or political opinion" within its definition of "refugee").

${ }^{3}$ Id.; see also Immigration and Nationality Act (INA) $\S 101(\mathrm{a})(42), 8$ U.S.C. $\S 1101(\mathrm{a})(42)(2012)$. 
over a decade of litigation on the issue of whether domestic violence could be a basis for asylum. ${ }^{4}$ The case was ultimately resolved in a nonbinding opinion in 2009,5 and this lack of direction from the courts led to continued confusion and inconsistent outcomes for applicants for years. ${ }^{6}$

Eventually, a second case involving a battered woman seeking asylum in the United States worked its way through the court system: Matter of $L-R-.^{7}$ After another lengthy appeals process, it too was ultimately resolved at the trial level, and therefore without precedential value. ${ }^{8}$ The lasting impact of Matter of $L-R$-, oddly enough, was not the final court decision but a lengthy and detailed brief from the Department of Homeland Security (DHS), the agency tasked with advancing the interests of the U.S. government in immigration proceedings, which articulated two frameworks for domestic violence asylum claims. ${ }^{9}$ DHS proposed that survivors of domestic violence who fit into two groups- "women in domestic relationships who are unable to leave" and "women who are viewed as property by virtue of their positions within a domestic relationship" - could be considered eligible for asylum protection in the United States. ${ }^{10}$ These two groups are now broadly accepted as the prevailing mechanism for advancing a winning domestic violence asylum claim and are widely utilized by advocates across the country.

Most recently, on August 26, 2014, a precedential decision on the issue of domestic violence as a basis for asylum was finally issued by the Board of Immigration Appeals (BIA), the highest administrative body to interpret U.S. immigration laws. ${ }^{11}$ In Matter of $A-R-C-G-$, the Board found that "married women in Guatemala who are unable to leave their relationship" constitutes a cognizable particular social group that can be the basis of an asylum claim. ${ }^{12}$

It is certainly a significant advancement to have a published, precedentsetting case acknowledging the validity of asylum claims based on domestic violence, because for years, DHS's brief in Matter of $L-R$ - had existed as de facto law, and survivors of intimate partner abuse lacked certainty when

${ }^{4}$ See infra Part III.C.

${ }^{5}$ In re Alvarado-Pena, [redacted] (Exec. Office for Immigration Review Dec. 10, 2009) (on file with author).

${ }^{6}$ See Blaine Bookey, Domestic Violence as a Basis for Asylum: An Analysis of 206 Case Outcomes in the United States from 1994 to 2012, 24 HASTINGS WOMEN's L.J. 107, 109 (2013).

${ }^{7}$ See Matter of L-R-, CTR. FOR GENDER \& REFUGEE STUD., http://cgrs.uchastings.edu /our-work/matter-1-r [https://perma.cc/G534-7ZDJ].

${ }^{8}$ Id.

${ }^{9}$ Department of Homeland Security's Supplemental Brief at 11, In re L-R-, [redacted] (B.I.A. Apr. 13, 2009) [hereinafter DHS 2009 Brief], http://cgrs.uchastings.edu/ sites/default/files/Matter_of_LR_DHS_Brief_4_13_2009.pdf [https://perma.cc/P8PV-A6FG].

${ }^{10} \mathrm{Id}$. at 14 .

${ }^{11}$ See In re A-R-C-G-, 26 I. \& N. Dec. 388, 388 (B.I.A. 2014).

${ }^{12} I d$. at $388-89$. 
advancing asylum claims. However, the social groups ${ }^{13}$ utilized to advance such claims are deeply problematic, as only certain types of survivors of domestic violence, namely stereotypically weak and powerless victims, are currently afforded protection under the existing law. ${ }^{14}$ And while the legal dimensions of asylum for women ${ }^{15}$ who have experienced and/or fear future domestic violence has been widely explored in the academic literature, the specific contours of the prevailing particular social groups used today-those articulated by DHS in Matter of $L-R-^{16}$ and accepted by the BIA in Matter of $A-R-C-G-17$ has not been the subject of scholarly analysis. Scholars and others have analyzed the significance of the public/private distinction and the nonstate actor in such claims ${ }^{18}$ and the relevance of the lack of government

${ }^{13}$ This Article will discuss and analyze both particular social groups proposed by the DHS in Matter of $L-R$ - - "women in domestic relationships who are unable to leave" and "women who are viewed as property by virtue of their positions within a domestic relationship"-because Matter of $A-R-C-G$ - was relatively recently decided by the BIA. See DHS 2009 Brief, supra note 9, at 14. Thus, although only the former group was articulated in the new case, see $A-R-C-G-, 26$ I. \& N. Dec. at 388-89, it remains to be seen whether the "viewed as property" formulation will diminish in importance.

${ }^{14}$ Stacy Brustin, Images of Women in U.S. Immigration Policy-The Paradox of Domestic Violence, 88 AM. SOC'Y INT'L L. Proc. 454, 457 (1994).

15 Although both men and women experience domestic violence, women are impacted at a significantly higher rate - one in four women have been the victim of severe physical violence by a partner as opposed to one in seven men. CTRS. FOR DISEASE CONTROL \& Prevention, National data on Intimate Partner Violence, Sexual Violence, and STALKING (2014), http://www.cdc.gov/violenceprevention/pdf/nisvs-fact-sheet-2014.pdf [https://perma.cc/D5GY-FABC]. In fact, between 1994 and 2010, four in five victims of domestic violence were female. Statistics, NAT'L Domestic Violence Hotline, http://www.thehotline.org/resources/statistics/ [https://perma.cc/RSZ4-LWJ5]. Other sources indicate that $85 \%$ of victims of domestic violence are women. CRYSTAL WICK, NAT'L CTR. ON DOMESTiC \& SeXUal Violence, FAQ on Domestic Violence 1 (Jan. 2004), http://www.ncdsv.org/images/DV_FAQs.pdf [https://perma.cc/9RMP-8BA9]. Women who suffer domestic violence are also subjected to more serious harms than male victims. See Office on Violence Against Women, U.S. DeP'T of Justice, 2012 BIENNIAL REPORT TO CONGRESS ON THE EFFECTIVENESS OF GRANT PROGRAMS UNDER THE Violence AgAinst WOMEN ACT 5 (2012), http://www.justice.gov/sites/default/files/ovw/1 egacy/2014/03/13/2012-biennial-report-to-congress.pdf [https://perma.cc/2NTS-MPSB] ("Although both men and women use violence in intimate partnerships, the most severe violence (i.e., involving broken bones, injury to bodily organs, sexual assault or coercion, and strangulation) is overwhelmingly inflicted by men against their women partners." (citation omitted)). Accordingly, this Article will use the feminine pronoun when referring to victims of domestic violence.

${ }^{16}$ DHS 2009 Brief, supra note 9, at 14.

$17 A-R-C-G-, 26$ I. \& N. Dec. at 388.

${ }^{18}$ E.g., Marisa Silenzi Cianciarulo, Batterers as Agents of the State: Challenging the Public/Private Distinction in Intimate Partner Violence-Based Asylum Claims, 35 HARV. J.L. \& GENDER 117 (2012); Nina Rabin, At the Border Between Public and Private: U.S. Immigration Policy for Victims of Domestic Violence, 7 LAW \& ETHICS HuM. RTs. 109 (2013). 
protection for survivors of family violence. ${ }^{19}$ Articles have also studied the use of the Convention Against Torture to aid women who are deemed ineligible for asylum ${ }^{20}$ and the effect the United States' and Canada's Safe-ThirdCountry Agreement has had on domestic violence asylum claims. ${ }^{21}$ It has even been argued that a new, gender-neutral social group should be added to U.S. asylum criteria in order to better analyze domestic violence-based asylum claims. $^{22}$

This Article takes a new and different approach, analyzing and critiquing the social groups proposed in Matter of $L-R$ - and codified by the BIA in Matter of $A-R-C-G-$, and ultimately arguing that they further a historical essentialization of battered women as helpless, passive, and powerless, which in turn perpetuates the victimization of domestic violence survivors. Unlike a "traditional" asylum claim based (to use a conventional example) on political opinion, where the applicant must demonstrate that she has affirmatively acted against authority, in the domestic violence context, the onus on the applicant is to show that she has not acted, that she has remained submissive and impotent in the face of harm and danger. The different standard for this gender-based claim results in an immigration policy that "fosters the notion of women as deserving of status [only] when they are perceived of as weak, passive victims. There is no public recognition of the strength of immigrant women nor of the significant contributions that they make on a daily basis to our society."23

Thus, as this Article will demonstrate, while the particular social group formulations in Matter of $L-R$ - and Matter of $A-R-C-G$ - may ultimately lead to protections for certain women, many others - in particular, those who do not fit the established profile of a tragic and helpless victim - are excluded. If Ana were to succeed in her hypothetical asylum claim, she would need to shed any portion of her narrative that involved her instigating or fighting back against her abuser; making a rational choice to remain with him due to familial, economic, or societal pressures; or terminating her relationship in a manner other than fleeing under cloak of darkness. Unless she were able to fit her square life into the round hole created by Matter of $L-R$ - and Matter of $A-R-C$ $G$-, Ana would risk being denied much needed protection in the United States. And even if Ana were permitted to remain in the safety of the United States,

${ }^{19}$ E.g., Elsa M. Bullard, Note, Insufficient Government Protection: The Inescapable Element in Domestic Violence Asylum Cases, 95 MinN. L. REV. 1867, 1867 (2011).

${ }^{20}$ E.g., Lori A. Nessel, "Willful Blindness" to Gender-Based Violence Abroad: United States' Implementation of Article Three of the United Nations Convention Against Torture, 89 MinN. L. REV. 71, 72-74 (2004).

${ }^{21}$ Lynn S. Hodgens, Note, Domestic Silence: How the U.S.-Canada-Safe-ThirdCountry Agreement Brings New Urgency to the Need for Gender-Based-Asylum Regulations, 30 VT. L. REV. 1045, 1045 (2006).

${ }^{22}$ Lynn Bayes-Weiner, Note, "Family Broils" and Private Terror: A Gender-Neutral, Psychologically-Based Approach to Domestic Violence and Asylum Law, 79 UMKC L. REV. 1047, 1048 (2011).

${ }^{23}$ Brustin, supra note 14, at 457. 
she may ultimately still be fundamentally harmed, as the Matter of $L-R$ - and Matter of $A-R-C-G$ - particular social groups disempower women by denying them the ability to claim a narrative of strength and agency.

Part II of this Article provides an introduction to the theory of Battered Woman Syndrome and the related principle of "learned helplessness" that provide the foundation for the pervasive image of the "vulnerable, ashamed ... dependent, unassertive, depressed, [and] defenseless" domestic violence victim. ${ }^{24}$ Part III then explains how the essentialized view of the battered woman has been applied in asylum law. A brief overview and history of domestic violence asylum in the United States is provided, including a review of the foundational Matter of $R-A$ - case and an analysis of the particular social groups for survivors of domestic violence articulated in Matter of $L-R$-: "women in domestic relationships who are unable to leave" and "women who are viewed as property by virtue of their positions within a domestic relationship." 25 It concludes by examining the most recent case in this area, Matter of $A-R-C-G-$, the first published BIA decision granting asylum to a survivor of domestic violence.

Part IV details why these particular social group formulations, premised on the stereotype of the helpless, docile, and passive battered woman, are problematic. Concerns are identified in four discrete areas: (1) the detrimental consequences of a woman's failure to conform to the prevailing victim narrative; (2) the contribution to victim blaming; (3) the lack of recognition and understanding of separation violence; and (4) the reliance on the binary narratives of either "good" or "bad," and "worthy" or "unworthy" immigrants. Lastly, proposed solutions and alternatives are explored in Part V, including the issuance of final regulations that would establish nonessentializing particular social groups for battered women. This Part also proposes and analyzes several alternative particular social group formulations that would enable survivors of domestic violence and their advocates to present counternarratives of women demonstrating strength, agency, and resilience in the face of abuse.

\section{BATTERED WOMAN SYNDROME AND LEARNED HELPLESSNESS}

\section{A. The Battered Woman}

In 1979, psychologist Lenore Walker published The Battered Woman, a groundbreaking book that would come to redefine the public and experts' view of victims of domestic violence. ${ }^{26}$ Walker, a self-identified feminist who was dissatisfied with existing explanations for why women remained in abusive

${ }^{24}$ Lisa A. Harrison \& Cynthia Willis Esqueda, Myths and Stereotypes of Actors Involved in Domestic Violence: Implications for Domestic Violence Culpability Attributions, 4 AgGRESSION \& Violent BeHAV. 129, 130 (1999).

${ }^{25}$ DHS 2009 Brief, supra note 9, at 14.

${ }^{26}$ LENORE E. WALKER, THE BATTERED WOMAN (1979). 
relationships, looked to psychology to explain patterns of behavior that caused women to stay. ${ }^{27}$ Her conclusion was that women remain in situations in which they experience domestic violence because of the phenomenon of "learned helplessness," a theory that victims are rendered helpless and dependent by the violence they suffer. ${ }^{28}$

To corroborate her thesis, Walker relied on interviews she conducted with 120 women (and "fragments of over 300 more stories"29), as well as studies conducted by psychologist Martin Seligman. ${ }^{30}$ In Seligman's experiments, dogs were placed "in cages and administered electrical shocks at random and varied intervals." 31 Unable to control the shocks, the dogs eventually stopped trying to escape and "became compliant, passive, and submissive." 32 And later, when the cage doors were opened and "the dogs were shown the way out, they remained passive, refused to leave, and did not avoid the shock."33

Based on this experiment and her interviews, Walker determined that "if an organism experiences situations which cannot be controlled, then the motivation to try to respond to such events when they are repeated will be impaired." 34 Essentially, she concluded that if you don't believe you have control over a negative occurrence, you stop trying to correct or prevent it. ${ }^{35}$ Analogizing to victims of domestic violence, she found that "[o]nce the women are operating from a belief of helplessness, the perception becomes reality and they become passive, submissive, "helpless." 36

${ }^{27} I d$. at $\mathrm{x}$-xi. Walker also acknowledged the role that a culture of patriarchy played in perpetuating domestic violence, as well as political and societal forces that subjugated women, including economic, legal and social dependence on men; the lack of safe housing alternatives; inadequate protection from police, courts, hospitals, and social service agencies; and pressures to keep families together. Id. at 43.

${ }^{28} \mathrm{Id}$. at 55. In addition to her observations about learned helplessness, Walker also introduced the "cycle theory of violence" that is now routinely used by professionals working with survivors of domestic violence to illustrate and explain the dynamics of an abusive relationship. Id. The cycle of violence includes "the tension-building phase; the explosion or acute battering incident; and the calm, loving respite." Id.

${ }^{29} I d$. at xiii.

${ }^{30} \mathrm{Id}$. at 45 .

${ }^{31} I d$. at 46 .

32 WALKER, supra note 26 , at 46.

${ }^{33} \mathrm{Id}$.

${ }^{34} \mathrm{Id}$. at 45 .

${ }^{35} \mathrm{Id}$.

${ }^{36}$ Id. at 47 . Walker also compared survivors of domestic violence to victims of major traumatic disasters. Id. at 49. She argued that unlike one-time events-such as hurricanes, earthquakes, and plane crashes - after which feelings of powerlessness fade, domestic violence was more akin to the experiences of those that that survived long-term or repeated traumas, such as Nazi concentration camps, that cause people to "become immune, passive, and convinced that they cannot do anything to help themselves." Id. 


\section{B. Critiques}

Walker's model for understanding domestic violence revolutionized thinking about the issue and became the predominant theory for understanding intimate partner violence in the 1980s and 1990s. Although popular and initially widely accepted, critiques of Battered Woman Syndrome soon emerged. First, Walker's data and methodology were called into question. ${ }^{37}$ The validity of her claims was also cast into doubt-most importantly here, the notion that all women who are in abusive relationships are uniformly helpless, meek, and passive. ${ }^{38}$ In fact, researchers have since shown that many women who are subjected to violence by their partners "are not the passive victims that notions of learned helplessness would imply," but that they instead "assertively and persistently attempt to do something about their abuse" but find that the available resources are not sufficient "to stop the cycle of violence." 39

Despite these concerns, Battered Woman Syndrome was incorporated into the U.S. legal system in numerous ways. It serves as the basis for the "Battered Woman's Defense," a self-defense theory that is utilized in attempts to exculpate survivors of domestic violence who harm or kill their abusers. ${ }^{40}$ Like the foundation upon which it is based, Battered Woman's Defense has also been subjected to much scientific and legal critique. ${ }^{41}$

${ }^{37}$ See, e.g., EdWARD W. GONDOLF \& Ellen R. FiSHER, BATtered WOMEN AS SURVIVORS: AN ALTERNATIVE TO TREATING LEARNED HELPLESSNESS 3 (1988) (stating that the theory of learned helplessness and notion that "battered women are basically passive and submissive in response to abuse" "appears to be rooted in assumptions and observations rather than hard fact"). See generally Robert F. Schopp et al., Battered Woman Syndrome, Expert Testimony, and the Distinction Between Justification and Excuse, 1994 U. ILL. L. REV. 45 (examining the empirical basis for the battered woman syndrome); David L. Faigman, Note, The Battered Woman Syndrome and Self-Defense: A Legal and Empirical Dissent, 72 VA. L. REV. 619 (1986) (discussing analytical and methodological criticisms).

${ }^{38}$ As Judith Herman explained in her influential book, Trauma and Recovery, "posttraumatic symptoms are ... wide-ranging." JUDITH LEWIS HERMAN, TRAUMA AND RECOVERY 49 (1992); see also Mary Ann Dutton, Understanding Women's Responses to Domestic Violence: A Redefinition of Battered Woman Syndrome, 21 HOFSTRA L. REV. 1191, 1196 (1993) ("The psychological realities of battered women do not fit a singular profile....").

${ }^{39}$ GONDOLF \& FiSHER, supra note 37 , at $91-93$.

40 "To some degree, most jurisdictions accept battered spouse syndrome evidence to support a claim of self-defense." 23A C.J.S. Criminal Procedure and Rights of Accused $\S 1505$, Westlaw (database updated Dec. 2016) (footnote omitted).

${ }^{41}$ See, e.g., Alafair S. Burke, Rational Actors, Self-Defense, and Duress: Making Sense, Not Syndromes, Out of the Battered Woman, 81 N.C. L. REV. 211, 211-12 (2002) (proposing an alternative approach that would treat battered women as rational actors and ask whether their use of defensive force was necessary); David L. Faigman \& Amy J. Wright, The Battered Woman Syndrome in the Age of Science, 39 ARIz. L. REV. 67, 69 (1997) ("The battered woman syndrome ultimately fails because it was never a matter of 
Lenore Walker's depiction of battered women as submissive, powerless, and unable to advocate for themselves also contributed to an increasingly aggressive criminal justice response to domestic violence. When signing the Violence Against Women Act (VAWA), ${ }^{42}$ a law that includes billions of dollars in funding for a broad array of measures designed to reduce the frequency of violence against women, President Bill Clinton cemented the connection between intimate partner violence and crime control when he stated that domestic violence is "the most important criminal justice issue in the United States." 43

Criminal interventions, some stemming from VAWA, ${ }^{44}$ include mandatory arrest and no-drop prosecution policies. Mandatory arrest laws compel police officers responding to domestic violence calls to make an arrest wherever there is probable cause to believe that an act of domestic violence has been committed, whether or not the victim seeks to have the batterer detained. ${ }^{45}$ No-drop prosecution requires prosecutors to proceed with criminal charges against alleged perpetrators of domestic violence, regardless of the victim's wishes. ${ }^{46}$ Both policies assume that the criminal justice system is better suited to make decisions about battered women's lives than the (presumed weak and powerless) women themselves. They have been widely criticized as a means for the legal system to disempower and remove agency and autonomy from survivors of domestic violence by supplanting the abuser's control with state control. ${ }^{47}$ Significantly here, scholars have also argued that

science to begin with, and yet it was treated as a 'scientific fact' by courts."); Cathryn Jo Rosen, The Excuse of Self-Defense: Correcting a Historical Accident on Behalf of Battered Women Who Kill, 36 AM. U. L. REV. 11, 18 (1986) (advocating for the creation of a new defense - excused self-defense - that would "accommodate many battered women's cases excluded by the justification theory without sacrificing the basic goals of the criminal law"); Faigman, supra note 37, at 622 (questioning the validity of Walker's research and arguing that courts should not admit expert testimony based on Battered Woman Syndrome). But see Kit Kinports, So Much Activity, So Little Change: A Reply to the Critics of Battered Women's Self-Defense, 23 ST. LouIS U. PuB. L. REV. 155 (2004) (responding to the criticisms of the Battered Woman's Defense).

42 Violence Against Women Act of 1994, Pub. L. No. 103-322, 108 Stat. 1796 (codified as amended in scattered sections of 28 and 42 U.S.C.).

43 Evan Stark, Coercive Control: The Entrapment of Women in Personal LIFE 21 (2007) (quoting President Bill Clinton).

${ }^{44}$ A significant percentage of VAWA funds are distributed to law enforcement agencies. In order to be eligible for certain federal funding, VAWA states must certify the adoption of policies that either encourage or mandate arrest of domestic violence offenders. 42 U.S.C. § 3796hh(c)(1) (2012).

${ }^{45}$ See Leigh Goodmark, Autonomy Feminism: An Anti-Essentialist Critique of Mandatory Interventions in Domestic Violence Cases, 37 FlA. ST. U. L. REV. 1, 3-4 (2009).

46 Id. at 4.

${ }^{47}$ See, e.g., id. (noting that mandatory arrest and no-drop policies "gave protection to women who had been abused with one hand, but took their freedom to choose with the other"); Laurie S. Kohn, The Justice System and Domestic Violence: Engaging the Case 
mandatory interventions, like Walker's Battered Woman Syndrome, erroneously "treat battered women as fragile, uncooperative, mentally ill, and/or indecisive." 48

Finally, as will be shown below in Part III, despite having been subjected to significant critique over the course of several decades, Battered Woman Syndrome and "learned helplessness" have also manifested in the immigration context; the prevailing particular social group formulations for domestic violence victims seeking asylum protection in the United States require women to demonstrate that they are the "property" of their abusers and are weak, passive, nonactors who are "unable to leave" their relationships. 49

\section{A BRIEF History of DOMESTIC ViOLENCE ASYLUM IN THE United STATES}

\section{A. Asylum and the Law of Particular Social Group}

To be eligible for asylum, an applicant must meet the definition of a refugee set forth in section 101(a)(42) of the Immigration and Nationality Act (INA):

any person who is outside any country of such person's nationality ... who is unable or unwilling to return to, and is unable or unwilling to avail himself or herself of the protection of, that country because of persecution or a wellfounded fear of persecution on account of race, religion, nationality, membership in a particular social group, or political opinion. ${ }^{50}$

This refugee definition is deceptively brief, as nearly each individual term within it has been the subject of significant litigation and academic discussion. ${ }^{51}$ Most relevant here is the penultimate phrase, "membership in a

but Divorcing the Victim, 32 N.Y.U. ReV. L. \& Soc. ChAnge 191, 211-25 (2008) (critiquing mandatory arrest and no-drop policies as suppressing of victims' voices); Dennis P. Saccuzzo, How Should the Police Respond to Domestic Violence: A Therapeutic Jurisprudence Analysis of Mandatory Arrest, 39 SANTA ClARA L. REV. 765 (1999) (proposing therapeutic jurisprudence and batterer re-education and healing as an alternative to mandatory prosecution). But see Cheryl Hanna, No Right to Choose: Mandated Victim Participation in Domestic Violence Prosecutions, 109 HARV. L. REV. 1849, 1909-10 (1996) (concluding that prosecutors, not victims, must make the final choice of whether or not to prosecute if law enforcement's goal is to send a message that domestic violence is unacceptable).

${ }^{48}$ Linda G. Mills, Killing Her Softly: Intimate Abuse and the Violence of State Intervention, 113 HARV. L. REV. 550, 584 (1999).

${ }^{49}$ DHS 2009 Brief, supra note 9, at 14. (2012)

${ }^{50}$ Immigration and Nationality Act (INA) § 101(a)(42), 8 U.S.C. § 1101(a)(42)

${ }^{51}$ See, e.g., Fatin v. Immigration \& Naturalization Serv., 12 F.3d 1233, 1238-39, $1238 \mathrm{nn} .4$ \& 5 (3d Cir. 1993) (citing cases and other sources "stuggl[ing] to define 'particular social group"'). 
particular social group," which is one of the five grounds upon which an applicant can base her claim for protection. 52 "Particular social group" is the most nuanced and complex of the grounds, and throughout the last several decades, courts have struggled with its interpretation..$^{53}$

The seminal decision interpreting the phrase is Matter of Acosta, which defines "particular social group" as comprising individuals who "share a common, immutable characteristic" that either cannot be changed or is so fundamental to the individuals' identities or consciences that they should not be required to change it. ${ }^{54}$ This shared characteristic might be an innate one such as sex, color, or kinship ties, or in some circumstances it might be a shared past experience such as former military leadership or land ownership..$^{55}$

Twenty years after Matter of Acosta, the BIA created two additional requirements: that any proposed particular social group possess "social visibility" 56 and be sufficiently "particular." 57 Taking each in turn, in Matter of $C$ - $A$-, the BIA explained that socially visible groups had "characteristics that were highly visible and recognizable by others in the country in question." 58 The court found that the particular social group of "former noncriminal drug informants working against the Cali drug cartel" 59 in Columbia was not visible, and therefore not viable, because "the very nature of the conduct at issue is such that it is generally out of the public view. In the normal course of events, an informant against the Cali cartel intends to remain unknown and undiscovered. ${ }^{\prime 60}$

528 U.S.C. $\S 1101$ (a).

53 The difficulty in defining the term "particular social group" has been unusually challenging due to the ambiguity of the phrase itself and the lack of legislative history surrounding its inclusion in the refugee definition. As then-Judge Samuel Alito stated:

Both courts and commentators have struggled to define "particular social group." Read in its broadest literal sense, the phrase is almost completely open-ended. Virtually any set including more than one person could be described as a "particular social group." Thus, the statutory language standing alone is not very instructive.

Nor is there any clear evidence of legislative intent.

Fatin, 12 F.3d at 1238-39 (footnotes omitted); see also Lwin v. Immigration \& Naturalization Serv., 144 F.3d 505, 510-11 (7th Cir. 1998) ("The legislative history behind the term ... is uninformative, and judicial and agency interpretations are vague and sometimes divergent. As a result, courts have applied the term reluctantly and inconsistently.").

${ }^{54}$ In re Acosta, 19 I. \& N. Dec. 211, 212 (B.I.A. 1985), overruled in part on other grounds by In re Mogharrabi, 19 I. \& N. Dec. 439 (B.I.A. 1987).

55 Id. at 233.

56 In re C-A-, 23 I. \& N. Dec. 951, 859-61 (B.I.A. 2006).

${ }^{57}$ In re A-M-E \& J-G-U-, 24 I. \& N. Dec. 69, 76 (B.I.A. 2007); see also In re S-E-G-, 24 I. \& N. Dec. 579, 582 (B.I.A. 2008).

${ }^{58} C-A-, 23$ I. \& N. Dec. at 960.

${ }^{59} \mathrm{Id}$. at $951,957$.

${ }^{60} \mathrm{Id}$. at 960 . 
Facing significant criticism of this analysis, in 2014 the BIA issued two decisions that clarified the social visibility requirement. In Matter of $M-E-V$ $G$ - and Matter of $W-G-R$-, the court asserted that Matter of $C-A$ - had improperly been understood as a requiring "ocular' visibility" and that what was in fact required was that the defined group possess "social distinction,"61 or "evidence showing that society in general perceives, considers, or recognizes persons sharing the particular characteristic to be a group." 62

In addition to possessing social visibility or distinction, a particular social group must also be sufficiently "particular." In Matter of $S-E-G-$, the BIA stated that the determining question when considering particularity is "whether the proposed group can accurately be described in a manner sufficiently distinct that the group would be recognized, in the society in question, as a discrete class of persons." 63 Particularity, therefore, as the court explained in Matter of $W-G-R-$, "addresses the question of delineation."64 Lastly, a viable particular social group also cannot be circular, meaning that it cannot be defined by the harm which the applicant claims as persecution. ${ }^{65}$

Although the criteria for what constitutes a viable particular social group have evolved over the last twenty years, at the time of publication of this Article, immutability, social distinction, particularity, and noncircularity are the four key requirements. And these factors are of great consequence in modern asylum claims, ${ }^{66}$ such as those based on domestic violence, sexual orientation, disability, or gang violence, which often rely on the particular social group ground.

Lastly, in addition to understanding particular social group, one additional area of asylum jurisprudence is important to explore here. An applicant for asylum must demonstrate not only that the persecution she fears is based on one of the five grounds delineated in the refugee definition, but also that the government of her home country is either the persecutory actor or "unable or

${ }^{61}$ In re M-E-V-G-, 26 I. \& N. Dec. 227, 228 (B.I.A. 2014); In re W-G-R-, 26

I. \& N. Dec. 208,216 (B.I.A. 2014).

$62 W-G-R-, 26$ I. \& N. Dec. at 217.

63 In re S-E-G-, 24 I. \& N. Dec. 579, 584 (B.I.A. 2008); see also In re A-M-E \& J-GU-, 24 I. \& N. Dec. 69, 73 (B.I.A. 2007).

$64 W-G-R-, 26$ I. \& N. Dec. at 214.

${ }^{65}$ See, e.g., Gomez v. Immigration \& Naturalization Serv., 947 F.2d 660, 663-64 (2d Cir. 1991) (rejecting the particular social group of "women who have been previously battered and raped by Salvadoran guerrillas").

66 The definition of a refugee in the 1951 Refugee Convention, upon which the U.S. refugee definition is based, was created with certain "archetypal refugees" in mind, "namely, the victims of political and religious persecution in Germany .... and [of] the Spanish Republicans." Barry Sautman, The Meaning of "Well-Founded Fear of Persecution" in United States Asylum Law and in International Law, 9 FORDHAM INT'L L.J. 483, 533-34 (1986). Thus, the drafters did not seem to have contemplated claims that are more common today, such as those alleging persecution based on sexual orientation or gender identity, disability, affiliation (or refusal to affiliate) with gangs, or gender (including female genital mutilation, forced marriage, and domestic violence). 
unwilling" to protect her from the persecution of a non-governmental actor. ${ }^{67}$ Cases involving so-called nonstate actors introduce an additional level of complexity to the asylum analysis, as establishing official unwillingness to control a persecutor, or government inaction, is often significantly more analytically and evidentiarily challenging than proving government action. ${ }^{68}$

\section{B. Matter of Kasinga}

In 1994, Fauziya Kassindja ${ }^{69}$ arrived in the United States, seeking protection from a forced polygamous marriage and female genital mutilation (FGM) in her home country of Togo. ${ }^{70}$ Detained upon arrival, she filed for asylum, and her claim was denied by the immigration judge. ${ }^{71}$ Upon review, however, the BIA granted Ms. Kassindja asylum based on her membership in the particular social group of "young women of the Tchamba-Kunsuntu Tribe who have not had FGM, as practiced by that tribe, and who oppose the practice." 72 The victory in Matter of Kasinga was groundbreaking, as it created precedent of gender-related harm constituting a basis for asylum protection in the United States.

\section{Matter of R-A-}

With the door to gender-based asylum opened by Matter of Kasinga, a case involving a different gender-related harm, domestic violence, soon worked its way through the courts: Matter of $R-A-{ }^{73}$ Ms. R-A-, whose full name is Rodi Alvarado, married her husband, a soldier in the Guatemalan army, when she was only sixteen years old. ${ }^{74}$ From the beginning of her marriage until she escaped to the United States a decade later, Ms. Alvarado

${ }^{67}$ See In re Acosta, 19 I. \& N. Dec. 211, 222 (B.I.A. 1985) (construing persecution as requiring that the claimed harm must be inflicted by the government of a country or by persons that the government is unable or unwilling to control), overruled in part on other grounds by In re Mogharrabi, 19 I. \& N. Dec. 439 (B.I.A. 1987).

${ }^{6}$ See, e.g., Michael G. Heyman, Asylum, Social Group Membership and the NonState Actor: The Challenge of Domestic Violence, 36 U. MicH. J.L. REFORM 767, 787-89 (2003); Mikhail Izrailev, Note, A New Normative Approach for the Grant of Asylum in Cases of Non-State Actor Persecution, 19 CARDOZO J. INT'L \& COMP. L. 171, 173 (2011).

${ }^{69}$ Ms. Kassindja's name was improperly transliterated as "Kasinga" in the process of her immigration proceedings, and as such, the official name of her case is recorded under this misspelled last name.

${ }^{70}$ In re Kasinga, 21 I. \& N. Dec. 357, 358 (B.I.A. 1996).

${ }^{71}$ Id. at $357-59$.

$72 \mathrm{Id}$. at 365 .

${ }^{73}$ In re R-A-, 22 I. \& N. Dec. 906 (B.I.A. 1999), vacated, 22 I. \& N. Dec. 906 (Att'y Gen. 2001), remanded, 23 I. \& N. Dec. 694 (Att'y Gen. 2005), stay lifted, 24 I. \& N. Dec. 629 (Att'y Gen. 2008).

${ }^{74}$ Id. at 908. 
faced horrifying and gruesome acts of violence at the hands of her spouse. ${ }^{75}$ He raped her almost daily, beating her before and during his violent sexual assaults. ${ }^{76} \mathrm{He}$ whipped her with an electrical cord and his military weapon. ${ }^{77}$ He used her head to break windows and mirrors and dislocated her jaw. ${ }^{78}$ When she became pregnant, he kicked her in her spine in an attempt to force an abortion. ${ }^{79}$ He threatened to maim and disfigure her if she ever left him. ${ }^{80}$

In the face of this increasing and near deadly violence, Ms. Alvarado fled to the United States and sought asylum. ${ }^{81}$ Originally granted asylum by the immigration judge, the BIA denied her claim ${ }^{82}$ after the then-Immigration and Naturalization Service (INS) ${ }^{83}$ appealed. ${ }^{84}$ The BIA concluded that Ms.

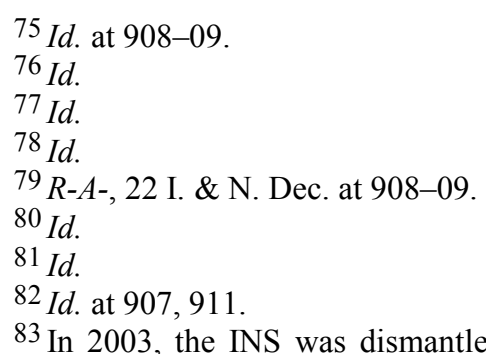

created DHS (that houses the U.S. Citizen Customs and Border Protection (CBP), and U.S. Immigration and Customs Enforcement (ICE)) and the Department of Justice (the agency that oversees the Immigration Court system). Our History, U.S. CITIZENSHIP \& IMMIGR. SERVS., https://www.uscis.gov/aboutus/our-history [https://perma.cc/7MJ4-8Y8L] (last updated May 25, 2011).

${ }^{84}$ Although a complete discussion is outside the scope of this Article, one possible explanation for the BIA's disparate treatment of Ms. Kassindja and Ms. Alvarado's claims is what Professor Leti Volpp describes as the use of culture to exoticize harms against women. Leti Volpp, Feminism Versus Multiculturalism, 101 CoLUM. L. REV. 1181, 1189 (2001). In her innovative essay, Feminism Versus Multiculturalism, Professor Volpp uses a vivid example to explain that "burning a woman to death in India is no more exotic than shooting a woman to death in the United States," and yet Americans consider bride burning a phenomenon that characterizes the entire culture of the nation of India, while domestic violence in the United States "reflect[s] the behavior of a few deviants." Id. at 1186-89. The BIA's decision in Matter of Kasinga contains a lengthy section entitled "Description of FGM" and focuses significant attention on the harms of what they repeatedly label as a "tribal" custom, suggesting that in viewing the violence that Ms. Kasinga suffered as foreign (and therefore perhaps even somewhat glamorous), the court felt more confident in its determination that FGM constituted persecution that merited asylum protection. In re Kasinga, 21 I. \& N. Dec. 257, 361-62, 372 (B.I.A. 1996). Similarly, in Matter of $S$ - $A$-, the BIA granted asylum to a girl who suffered domestic violence at the hands of her father, who beat her to punish her for what he perceived as her liberal religious beliefs, which differed from what the court described as her father's "fundamentalist Muslim beliefs" concerning the proper role of women in Moroccan society. In re S-A-, 22 I. \& N. Dec. 1328, 1330-31 (B.I.A. 2000). Matter of $S$ - $A$ - can be differentiated from Matter of $R$ - $A$-, as it was decided on religion, as opposed to particular social group, grounds and was a case of child, not spousal, abuse. See id. However, an examination of both Matter of Kasinga and Matter of $S$ - $A$ - "suggests that the decisions to grant asylum in [both cases was] largely due to the vilification of non-Western culture rather than an acknowledgement that claims involving gender-related persecution indeed fit within asylum jurisprudence." Anita Sinha, 
Alvarado's persecution was not on account of her membership in the proposed particular social group of "Guatemalan women who have been involved intimately with Guatemalan male companions, who believe that women are to live under male domination." 85 The court based its reasoning on several factors, including its skepticism that "anyone in Guatemala perceives this group to exist in any form whatsoever," 86 effectively, a lack of social distinction. ${ }^{87}$

The BIA's denial of Matter of $R$ - $A$ - launched a series of remarkable legal events. In December of 2000, the Department of Justice (DOJ), largely in response to the Board's decision, issued a proposed rule that provided guidance on gender-based asylum claims. ${ }^{88}$ In 2001, Attorney General Janet Reno vacated the BIA's decision in Matter of $R$ - $A$ - and ordered the case to be remanded to the Board for consideration after the proposed rule was finalized. ${ }^{89}$ Exactly four years later, with no movement on the proposed rule, Attorney General John Ashcroft recertified Matter of $R$ - $A$ - to himself. ${ }^{90}$ As a result, and in a most striking turn of events, DHS filed a brief in which it supported a grant of asylum for Ms. Alvarado. ${ }^{91}$

Domestic Violence and U.S. Asylum Law: Eliminating the "Cultural Hook" for Claims Involving Gender-Related Persecution, 76 N.Y.U. L. REV. 1562, 1583 (2001). Thus, it may be inferred that the BIA was not as willing to grant asylum when faced with a less exotic claim, one based on the more commonplace harm of domestic violence, in Matter of $R-A$ -

${ }^{85} R-A-, 22$ I. \& N. Dec. at 917.

${ }^{86} \mathrm{Id}$. at 918.

${ }^{87}$ See In re M-E-V-G-, 26 I. \& N. Dec. 227, 228 (B.I.A. 2014); In re W-G-R-, 26 I. \& N. Dec. 208, 212 (B.I.A. 2014).

${ }^{88}$ Asylum and Withholding Definitions, 65 Fed. Reg. 76588 (proposed Dec. 7, 2000) (to be codified at 8 C.F.R. $\S 208.13$ ).

${ }^{89}$ OfFICE OF THE ATT'Y GeN., ORDER No. 2379-2001 (Jan. 19, 2001), https://cgrs.uchastings.edu/sites/default/files/AG_Reno_RA_Order_01_19_2001.pdf [https:// perma.cc/VL7K-KV3P].

${ }^{90}$ Matter of $R$ - $A$-, CTR. FOR GENDER \& REFUGEE STUD., https://cgrs.uchastings.edu//o ur-work/matter-r [https://perma.cc/EC8U-PSBY].

${ }^{91}$ Department of Homeland Security's Position on Respondent's Eligibility for Relief at 3, In re Alvarado-Pena, No. A 73753922 (Att'y Gen. Feb. 19, 2004), https://cgrs.uchastings.edu/sites/default/files/Matter\%20of\%20R-A-\%20DHS\%20brief.pdf [https://perma.cc/F9DA-2SE9]. DHS' request was that Ms. Alvarado receive asylum due to the "particularly horrendous abuse" she suffered, but the agency was careful to note that it was not arguing that all survivors of domestic violence were entitled to asylum. $I d$. at 2 . In fact, DHS argued forcefully for a limited holding, noting that " $[t]$ he facts of this case ... do not offer an appropriate vehicle for developing the kind of a comprehensive administrative interpretive approach needed for the adjudication of particular social group cases." Id. at 23. DHS's position was that the issuance of a final rule would be the most appropriate vehicle for a final resolution of claims like those advanced in Matter of $R$ - $A$ - and urged "the Attorney General to instruct the Board to grant asylum in this case without issuing an opinion ... so as not to prejudice the rulemaking process." Id. DHS further requested that if the case were decided prior to the issuance of a final rule, that the decision be "narrowly tailored and limited as much as possible to the particular facts of this case, to allow development of the applicable law through the rule-making process." Id. at 4. 
DHS's reversal of position in Matter of $R$ - $A$ - signaled an increasing acceptance of asylum claims based on domestic violence. In its brief, DHS articulated a new particular social group into which it felt Ms. Alvarado belonged: "married women in Guatemala who are unable to leave the relationship." 92 The DHS brief marked the first time that this social group formulation, one that would become entrenched in domestic violence asylum claims in the years to follow, was officially posited. In articulating its basis for the group, DHS focused on both the specific characteristics that caused Ms. Alvarado's husband to harm her, as well as the complicity of Guatemalan society in his violence. ${ }^{93}$

After reviewing DHS's revised position, Attorney General Ashcroft once again remanded the case to the BIA, with orders that it be decided when the proposed rule was finalized. ${ }^{94}$ Three more years passed, and in 2008, a new attorney general, Michael Mukasey, ordered the BIA to decide the case without waiting for the final rule..$^{95}$ The Board then remanded the case to the immigration judge. ${ }^{96}$ In December of 2009, after a fourteen year legal battle, an immigration judge in San Francisco granted Rodi Alvarado asylum. ${ }^{97}$

Of course, because the grant of asylum was issued by an immigration judge as opposed to the appellate level BIA, the ruling did not create binding precedent. And because the proposed rule drafted in 2000 had not yet been finalized, this left a jurisprudential vacuum and the opportunity for the emergence of a second significant case in the area of domestic violence asylum: Matter of $L-R$ -

\section{Matter of L-R-}

The tragic circumstances experienced by the applicant in Matter of $L-R$ are strikingly similar to the harms faced by Rodi Alvarado. Born in Mexico, Ms. L-R- met the man who would become her tormenter and the father of her children when she was nineteen years old. ${ }^{98} \mathrm{He}$ was thirty-three and came

$92 \mathrm{Id}$. at 15 .

${ }^{93} I d$. at $26-27$ ("The social group in this case is best defined in light of the evidence that Alvarado's husband believes that women should occupy a subordinate position within a marital or intimate relationship, that Alvarado must remain in this subordinate position in the relationship, that abuse of women within such a relationship can therefore be tolerated, and that social expectations in Guatemala reinforce this view.").

94 In re R-A-, 23 I. \& N. Dec. 694, 694 (Att'y Gen. 2005).

95 In re R-A-, 24 I. \& N. Dec. 629, 629 (Att'y Gen. 2008).

${ }^{96}$ Matter of $R$-A-, supra note 90.

${ }^{97}$ In re Alvarado Pena, [redacted] (Exec. Office for Immigration Review Dec. 10, 2009) (on file with author). The immigration judge's decision was brief, reading simply, "Inasmuch as there is no binding authority on the legal issues raised in this case, I conclude that I can conscientiously accept what is essentially the agreement of the parties [to grant asylum]." Id.

98 Matter of L-R-, supra note 7. 
from a wealthy and influential family. ${ }^{99} \mathrm{~A}$ week after they first encountered one another, he dragged her to his home and demanded that she be his girlfriend.100 When Ms. L-R- refused, she was beaten and sexually assaulted. ${ }^{101}$

For the next twenty years, Ms. L-R- was subjected to atrocious brutality. ${ }^{102}$ She was held captive by her abuser, who beat and raped her almost daily, often at gunpoint. ${ }^{103}$ When she became pregnant with her first child, she attempted to flee; her abuser found her and tried to burn her alive in retaliation. ${ }^{104}$ The physical, mental, and verbal torment continued, and he regularly used threats of violence against Ms. L-R-'s family and their children as a means to control her and prevent her escape. 105

Ms. L-R- fled to the United States in 2004 and applied for asylum. ${ }^{106}$ When her claim was denied by the immigration judge, she appealed to the BIA. ${ }^{107}$ DHS initially defended the IJ's ruling, but in a supplemental briefing, the DHS reversed its position. ${ }^{108}$ Citing the "long-unsettled state of U.S. law as it applies to [domestic violence] claims," DHS "depart[ed] from normal practice" and used its brief in Matter of $L-R$ - to articulate the agency's official position regarding such claims and propose formulations of particular social groups that the Agency believed would be viable for women seeking asylum based on domestic violence. ${ }^{109}$

DHS first argued that the particular social group posited by Ms. L-R-'s attorneys-"Mexican women in an abusive domestic relationship who are unable to leave"-was impermissibly circular. ${ }^{110}$ It then posited two alternative groups: "Mexican women in domestic relationships who are unable to leave" and "Mexican women who are viewed as property by virtue of their positions within a domestic relationship" and explained how each met the immutability, visibility, and particularity requirements. ${ }^{111}$ Like in its Matter of $R$ - $A$ - brief, DHS stated that it crafted these particular social groups with a view

${ }^{99}$ Brief of Respondents in Support of Applications for Asylum, Withholding of Removal and CAT Relief at 6, In re L-R-, [redacted] (Exec. Office for Immigration Mar. 10, 2010) [hereinafter Brief of Respondents], https://cgrs.uchastings.edu/sites/default/files/

L-R-_brief_immigration_court_03_10_2010.pdf [https://perma.cc/MCZ8-ULH9] .

${ }^{100} \mathrm{Id}$. at 7.

${ }^{101} \mathrm{Id}$.

102 See generally id.

${ }^{103}$ Id. at $7-10$.

$104 \mathrm{Id}$. at 10.

105 Brief of Respondents, supra note 99, at 10-21.

106 Id. at 21-22.

107 Matter of L-R-, supra note 7.

108 Supplemental briefing was ordered by the BIA “ "in view of' the Attorney General's recent decision in Matter of R-A-." DHS 2009 Brief, supra note 9, at 3 (quoting the BIA's December 23, 2008 supplemental briefing notice).

${ }^{109} \mathrm{Id}$. at $4-5$.

${ }^{110} \mathrm{Id}$. at $10-11$ (quoting the immigration court).

${ }^{111} \mathrm{Id}$. at $14-16$. 
towards both the victim and the society in which she lived, stating that because "a cognizable particular social group must reflect social perceptions or distinctions," 112 it is "best defined in light of the evidence about how the respondent's abuser and her society perceive her role within the domestic relationship," which in this case is that "women should occupy a subordinate position."113

After the supplemental briefings before the BIA, Matter of $L-R$ - was remanded to the immigration judge. ${ }^{114}$ DHS stipulated that Ms. L-R- was eligible for asylum, and on August 4, 2010, she was granted asylum in a summary order, once again, a procedural history that left future survivors and domestic violence advocates without binding precedent upon which to rely. ${ }^{115}$

\section{E. Matter of A-R-C-G-}

After decades of uncertainty and ambiguity during both the pendency and after the resolution of Matter of $R-A$ - and Matter of $L-R$-, the BIA issued a precedent decision addressing the eligibility of survivors of domestic violence for asylum on August 26, 2014. In Matter of $A-R-C-G$ - the Board considered the case of a woman from Guatemala, who like Ms. Alvarado and Ms. L-R-, was subjected to brutal abuse at the hands of her intimate partner. ${ }^{116}$ After she married at age seventeen, her husband beat her weekly, broke her nose, threw paint thinner on her, burned her breast, and raped her regularly. ${ }^{117}$ When she sought help from law enforcement, the police refused to "interfere in a marital relationship," and Ms. A-R-C-G-'s husband threatened her with death if she involved them again. ${ }^{118}$ The BIA found, and DHS conceded, that the abuse Ms. A-R-C-G- suffered was on account of her membership in the particular social group of "married women in Guatemala who are unable to leave their relationship."119 The fact that DHS did not oppose a grant of asylum on this ground, ${ }^{120}$ and the BIA's adoption of the particular social group language utilized for years after the issuance of the DHS brief in Matter of $L-R$-, speaks volumes about the extent of the "unable to leave" formulation's penetration into the legal culture of domestic violence-based asylum law.

112 Id. at 17 .

${ }^{113} \mathrm{Id}$. at 14 .

${ }^{114}$ Matter of L-R-, supra note 7.

${ }^{115}$ Much like the final order in Matter of $R-A$-, this decision is also extremely brief. The order states that asylum is granted, with a notation that the grant was a result of "stipulation of the parties." Id. (quoting the summary order).

116 In re A-R-C-G-, 26 I. \& N. Dec. 388, 389-90 (B.I.A. 2014).

117 Id. at 389.

118 Id.

${ }^{119}$ Id. at $388-89$.

${ }^{120}$ DHS instead sought to have the case remanded for "further factual development" prior to final resolution of the claim. Id. at 390. 
It is certainly a laudable advancement that domestic violence claims are now officially recognized by the immigration court system, as for many years the ability of survivors of spousal or intimate partner abuse to obtain protection in the United States was significantly more limited and uncertain. However, although the situation has improved, it remains far from ideal. The prevailing social group formulations articulated by the DHS in Matter of $L-R$ ("Mexican women in domestic relationships who are unable to leave" and "Mexican women who are viewed as property by virtue of their positions within a domestic relationship") ${ }^{121}$ as well as the similar "unable to leave" group accepted by the BIA in Matter of $A-R-C-G-, 122$ are deeply problematic. As will be discussed in detail in Part IV below, these particular social groups further the essentializing narrative of battered women as pitiable and helpless victims, and asylum law's adaption of Lenore Walker's victim-focused framework significantly limits the ability of a survivor of domestic violence to articulate or present a counternarrative of empowerment in her case.

\section{The Problematic AsPects of Asylum LaW's Use of Particular SOCIAL GROUPS THAT FURTHER THE HELPLESS BATTERED WOMAN NARRATIVE}

\section{A. The Power of Narrative and Danger of Stock Stories}

Narrative, or storytelling, has always been an essential aspect of everyday life, but it has increasingly gained attention as critical to lawyering. ${ }^{123}$ Because narrative "is our most basic form of communication and the primary lens through which we understand day to day human experience," it is only natural that lawyers seek to use stories in the courtroom or in conducting other forms of legal advocacy for their clients. ${ }^{124}$ But while the utility of narrative is clear, it is possible to have too much of a good thing; an overreliance on particular

${ }^{121}$ DHS 2009 Brief, supra note 9, at 14

122 In re A-R-C-G-, 26 I. \& N. Dec. 388, 389-90 (B.I.A. 2014).

123 See generally Kathryn Abrams, Hearing the Call of Stories, 79 CALIF. L. REV. 971 (1991) (examining feminist narratives in legal scholarship); Sally Frank, Eve Was Right to Eat the "Apple": The Importance of Narrative in the Art of Lawyering, 8 YALE J.L. \& FEMINISM 79 (1996) (demonstrating how narrative could be utilized to craft a hypothetical defense for the biblical character Eve); Lawyers as Storytellers \& Storytellers As Lawyers: An Interdisciplinary Symposium Exploring the Use of Storytelling in the Practice of Law, 18 VT. L. REV. 567 (1994) (examining the role of storytelling more generally in the legal profession); Symposium, Legal Storytelling, 87 MicH. L. REV. 2073 (1989) (same); Binny Miller, Give Them Back Their Lives: Recognizing Client Narrative in Case Theory, 93 MicH. L. REV. 485 (1994) (exploring the intersection between case theory and client narrative)

124 John B. Mitchell, Narrative and Client-Centered Representation: What Is a True Believer to Do When His Two Favorite Theories Collide?, 6 ClinICAL L. REV. 85, 85-86 (1999) (footnote omitted). 
narratives can, if overused or utilized without purpose in the absence of critical analysis, become static and inescapable stock stories. ${ }^{125}$

Like narrative, stock stories, or schema, ${ }^{126}$ can be useful. Faced with an endless stream of stimuli in our daily lives, schema help us assign meaning to the information we receive, limit unnecessary processing, and allow us to draw inferences about what might happen in the future. ${ }^{127}$ However, as Professor Gerald López writes, while "stock stories embody our deepest human, social and political values" and "help us carry out the routine activities of life without constantly having to analyze or question what we are doing[,] . . they also may disguise and distort." 128 When stock stories become the sole lens though which a client or experience is viewed, and/or when they serve to perpetuate stereotypes or limit open-mindedness or free-thinking, they are highly problematic. ${ }^{129}$ And when narrative evolves to a unitary stock story-a legal category or conception that one must adhere to in order to receive protection - it becomes a dangerous legal weapon. This is precisely what has occurred in domestic violence asylum law.

${ }^{125}$ Nicole E. Negowetti, Navigating the Pitfalls of Implicit Bias: A Cognitive Science Primer for Civil Litigators, 4 St. MARY's J. Legal MALPRACTICE \& ETHICS 278, 301 (2014) (explaining that stock stories create implicit biases that affect the way stories are told in the courtroom).

${ }^{126}$ Stock stories and schema are generally defined as "stories [that] help us interpret the everyday world with limited information and help us make choices about asserting our own needs and responding to other people." Gerald P. López, Lay Lawyering, 32 UCLA L. REV. 1, 3 (1984). For more on stock stories and schema, see generally ANTHONY G. AMSTERDAM \& JEROME BRUNER, Minding the LAW: HOW COURTS RELY ON StOrytelling, and How Their Stories Change the Ways We Understand the LAW-AND OURSELVES 121 (2000); STEPHEN ELLMANN ET AL., LAWYERS AND CLIENTS: CRITICAL ISSUES IN INTERVIEWING AND COUNSELING 176-80 (2009); and Albert J. Moore, Trial by Schema: Cognitive Filters in the Courtroom, 37 UCLA L. REV. 273 (1989).

${ }^{127}$ Stefan Krieger and Richard Neumann provide a short but illustrative example of the function of schema in the everyday world:

When we go to a restaurant ... and a person comes to our table with a pad and pencil, we do not expect that the person is going to ask for an autograph or take dictation, but without giving the situation a second thought, we anticipate that the person will take our order.

Stefan H. Krieger \& Richard K. Neumann, JR., Essential LaWyering Skills: Interviewing, Counseling, Negotiation, And Persuasive Fact ANalysis 145 (5th ed. 2015).

${ }^{128}$ López, supra note 126 , at 3.

129 Author Chimamanda Ngozi Adichie explains the danger of stock stories and stereotypes like this: "The single story creates stereotypes, and the problem with stereotypes is not that they are untrue, but that they are incomplete. They make one story become the only story." Chimamanda Ngozi Adichie, The Danger of a Single Story, TED (Oct. 2009), https://www.ted.com/talks/chimamanda_adichie_the_danger_of_a_single_stor

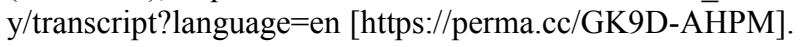




\section{B. The Consequences of Failure to Conform to the Prevailing Victim Narrative}

As a result of the proliferation of the Battered Woman Syndrome narrative and the ensuing stock story - the myth of the helpless abused womansurvivors of domestic violence who fail to conform to this paradigmatic powerless and docile victim role are at risk of not obtaining the legal protections they desperately need. ${ }^{130}$ As Professor Leigh Goodmark describes, women - particularly women of color and lesbians - who do not fit neatly into the prevailing narrative are often denied orders of protection when they fight back against their attackers or refuse to admit fear. ${ }^{131}$ Similarly, Professor Laurie Kohn explains that a nonpassive victim of domestic violence who expresses anger towards her assailant may be deemed incredible and denied a protection order. ${ }^{132}$ Finally, Professor Evan Stark shares a case study in which a survivor of violence was "tearful and frightened outside the court, [but] in the courtroom she appeared defiant," leading the court to view her as "an aggressive, demanding, even 'rude' mother." 133 These injustices in the civil context-victims being required to conform their narratives to a particular stock story in order to be safe - endure in the realm of asylum law. ${ }^{134}$

While preconceived notions regarding the way victims of domestic violence should behave may lead to injustice in a civil proceeding because decision-makers are not hearing the narrative they expect, they seem certain to doom the claim of an asylum applicant who is not always passive or submissive to her abuser because the notion of the "helpless victim" is written into asylum law. As discussed above, the prevailing particular social group formulations in domestic violence-based asylum cases require a woman to prove that she has been "unable to leave" her abuser or that he views her as his property. ${ }^{135}$ This necessitates an applicant telling a particular type of story to the asylum adjudicator, namely, that she is docile and powerless. She must show that she could never muster the strength or internal fortitude to stand up to her abuser and leave, that she was viewed as, and likely even felt like, chattel.

${ }^{130}$ See Adele M. Morrison, Changing the Domestic Violence (Dis)Course: Moving from White Victim to Multi-Cultural Survivor, 39 U.C. DAVIS L. REV. 1061, 1085 (2006) ("[O]ne must be a victim - a particular kind of victim - in order to get help. An inability to show one's victim status may result in a failure to obtain the assistance one needs." (footnote omitted)).

${ }^{131}$ Leigh Goodmark, When Is a Battered Woman Not a Battered Woman? When She Fights Back, 20 YALE J.L. \& FEMINISM 75 (2008) (explaining how women who fight back are often not viewed as victims).

${ }^{132}$ Laurie S. Kohn, Barriers to Reliable Credibility Assessments: Domestic Violence Victim-Witnesses, 11 AM. U. J. GENDER \& SOC. POL'Y \& L. 733, 739 (2003).

133 Evan Stark, Re-Presenting Woman Battering: From Battered Woman Syndrome to Coercive Control, 58 ALB. L. REV. 973, 1012-13 (1995).

134 See Goodmark, supra note 131 , at 82 .

${ }^{135}$ See In re A-R-C-G-, 26 I. \& N. Dec. 388, 393 (B.I.A. 2014). 
Although some survivors of domestic violence may in fact fit this profile, many others do not. ${ }^{136}$ Ana, the fictional client profiled in the Introduction to this Article, serves as an example of such a woman. Her story does not comport neatly with the narrative of helplessness, as Ana not only fought back against her abusive husband through retaliatory or protective physical violence of her own, but she actively instigated his attacks in an effort to shield herself and her child from further harm. Moreover, Ana does not fit the stock story or expected narrative of the domestic violence victim finally pushed to the brink and furtively escaping in the dead of night. Instead, Ana made a difficult and rational choice to leave after her abuser permitted her to do so; her situation can therefore be more appropriately expressed as being unable to return as opposed to unable to leave. Thus, unless Ana and her lawyers ignore the aspects of her story that highlight her clear thinking and opposition to being viewed as a piece of property that her abuser can dispense with as he pleases, she may not be considered eligible for asylum protection. ${ }^{137}$

But even if a woman is able to obtain asylum, the harm of the existing particular social groups is not necessarily avoided. Asylum law exists to provide protection to refugees - individuals who have faced unspeakable horrors in their home countries and fear further harm if they are returned. Thus, the need to tell a tragic story may be demanded in any asylum claim, regardless of the basis for protection. However, if, for example, a political activist is seeking asylum for speaking out against abuses committed by her

136 See Dutton, supra note 38, at 1196.

${ }^{137}$ It should be noted that women who refuse to submit to their abusers may be able to make an asylum claim based on their political opinion. See In re R-A-, 22 I. \& N. Dec. 906, 913 (B.I.A. 1999), vacated, 22 I. \& N. Dec. 906 (Att'y Gen. 2001), remanded, 23 I. \& N. Dec. 694 (Att'y Gen. 2005), stay lifted, 24 I. \& N. Dec. 629 (Att'y Gen. 2008); Matter of $L-R$-, supra note 7. In fact, both Matter of $R-A$ - and Matter of $L-R$ - argued that they were persecuted not only based on their membership in a particular social group but also their assertion of a feminist political opinion that includes defiance of male domination. $R-A$-, 221 I. \& N. Dec. at 915-18; Matter of L-R-, supra note 7. However, the results in Matter of $R$ - $A$ - and Matter of $L-R$ - demonstrate clearly why a domestic violence survivor's cannot reliably utilize political opinion as a basis of protection, as the political opinion claims were rejected in both cases. $R-A-, 221$ I. \& N. Dec. at 915-18; Matter of $L-R-$, supra note 7. In making its determination, the BIA in Matter of $R-A$ - and DHS in Matter of $L$-R-cited the high evidentiary bar established in Immigration \& Naturalization Service v. EliasZacarias, 502 U.S. 478, 483 (1992), which requires an applicant to provide evidence that her political opinion motivated the persecutor to harm her. $R-A-, 221$ I. \& N. Dec. at 912 13, 916 ("What we find lacking in this respondent's showing, however, is any meaningful evidence that her husband's behavior was influenced at all by his perception of the respondent's opinion."); see also DHS 2009 Brief, supra note 9, at 22 (“[T]here is no record evidence to reflect that, even if [redacted] was aware of the female respondent's feminist views and opposition to dominance, his abuse was related to her opinions on this matter."). This difficulty in establishing a viable political opinion claim in domestic violence asylum cases, along with the stated position of DHS preferring social group claims in such cases, leaves particular social group as the most viable option for survivors of domestic violence. 
home country's government, she is permitted under existing law to tell a story of both victimization and empowerment. In her asylum application and testimony, she may speak of how she fought against oppression and was jailed, tortured, or (like a domestic violence victim) beaten and raped as a result. The current particular social group formulations in domestic violence claims do not allow survivors of domestic abuse to tell the first half of this story-the aspects of their narrative that show them fighting against subjugation. Strength or dignity must be eradicated from their narrative. There is only one way to prevail, and that is to be completely powerless.

The effective inability of a survivor of domestic violence to tell her authentic story, one that may involve a combination of power and powerlessness, is a profound violation perpetrated by the legal system. As Professor Ann Shalleck describes, "[i]n order to secure what legal protections exist, [survivors] often must violate their own understanding of themselves and conform to the dominant stereotype," forcing them to lose themselves in the process. ${ }^{138}$ Similarly, the pressure to conform to the "ideal" meek and impotent victim narrative denies an abused woman the opportunity to (re)claim her identity as a "free person[] entitled to a liberatory response."139 In effect, the legal requirements of the asylum system serve to control and potentially coopt a survivor's sense of self, ironically, an action previously undertaken by her abusive partner.

The experiences survivors of domestic violence have with the justice system already possess a significant element of essentialization, making "one characteristic of a woman's experience define her entire identity, thereby marginalizing or trivializing other aspects of her identity..... Her strengths and her accomplishments become submerged under the label of 'battered woman." 140 This may be particularly true in the case of immigration law, a

138 Ann Shalleck, Theory and Experience in Constructing the Relationship Between Lawyer and Client: Representing Women Who Have Been Abused, 64 TENN. L. REV. 1019, 1026 (1997).

${ }^{139}$ STARK, supra note 43 , at 16 . Stark notes that although he does not necessarily agree with "conservative feminists" who claim that the severity of male violence is exaggerated, writers such as Camille Paglia and Kate Rophie are right to challenge rhetoric that focuses exclusively on victimization. $I d$. at 9 . He further argues that this singular view of women as victims, as well as the recognition of only physical violence and not the more nuanced effects of male domination as constituting domestic violence, allows for the maintenance of the prevailing social hierarchy of men over women. Id.

${ }^{140}$ Shalleck, supra note 138, at 1023; see also Martha R. Mahoney, Legal Images of Battered Women: Redefining the Issue of Separation, 90 MicH. L. REV. 1, 25 (1991). Professor Mahoney describes a woman interviewed at a domestic violence shelter who explained that '[i]t's difficult to accept yourself as a 'battered wife' as the term isn't right. I have had a lot of marital troubles, which have included violence. Despite all my attempts to make the marriage work, I had no choice but to get away." Id. (quoting Joy Melville, Some Violent Families, in ViOLENCE AND THE FAMILY 9, 10 (J.P. Martin ed., 1978)). Mahoney emphasizes that "[s]he defines herself as active, working to solve her problems, reaching out for solutions. These actions conflict with her sense of what a 'battered wife' is." Id. (footnote omitted). 
realm in which the means by which lawful status is gained becomes a key part of one's identity formation as an American citizen or resident of the United States. ${ }^{141}$ Here, a domestic violence survivor who is ultimately able to secure asylum protection forms her immigrant identity based on powerlessness.

Thus, as demonstrated above, because stories are how we define ourselves, how we create and shape our identities, counternarratives of strength and empowerment are critically important, especially to those who have survived intimate partner violence. Returning to the concept of stock stories, Professor Richard Delgado succinctly explains how such unitary narratives can become problematic:

Narrative habits, patterns of seeing, shape what we see and that to which we aspire. These patterns of perception become habitual, tempting us to believe that the way things are is inevitable .... Alternative visions of reality are not explored, or, if they are, rejected as extreme or implausible. ${ }^{142}$

Conversely, counterstories "challenge the received wisdom," "showing us that there are possibilities for life other than the ones we live." 143 As Professor Delgado eloquently states:

Stories, parables, chronicles, and narratives are powerful means for destroying mindset - the bundle of presuppositions, received wisdoms, and shared understandings against a background of which legal and political discourse takes place. These matters are rarely focused on. They are like eyeglasses we have worn a long time. They are nearly invisible; we use them to scan and interpret the world and only rarely examine them for themselves. ${ }^{144}$

In the area of domestic violence, where power and control are widely understood to be the primary tools of abuse, ${ }^{145}$ the fact that a woman cannot push back against the stock story by telling a counterstory that allows her to assume and proclaim her identity as a powerful agent is particularly lamentable. As experts have noted, a battered woman is further disempowered when, "rather than having faith in the validity of her story, she is counseled to

${ }^{141}$ See, e.g., Guy Raz, What Does Identity Mean for an Immigrant?, NPR (Oct. 11, 2013), http://www.npr.org/templates/transcript/transcript.php?storyId=229881828 [https:// perma.cc/F762-DTPQ].

142 Richard Delgado, Storytelling for Oppositionists and Others: A Plea for Narrative, 87 MicH. L. REV. 2411, 2416-17 (1989) (footnote omitted).

143 Id. at 2414.

${ }^{144} I d$. at 2413 (footnote omitted).

145 "Power and control" is generally understood as the "interrelated dimensions of physical abuse, economic abuse, coercion and threats, intimidation, emotional abuse (using isolation, minimizing, denying, and blaming), and abusing male privilege." ELIZABETH M. SCHNEIDER, BATTERED WOMEN \& FEMINIST LAWMAKING 12 (2000). 
retell the incident to make it more suitable for the [legal system]."146 Thus, "[n]arratives that enable a woman to see that she is not responsible for the violence against her, and that she is actively struggling against that violence, can be an essential tool in helping her hold on to her sense of self." 147 This is why feminist scholars focus on women's agency, in the hope that doing so can "provide a more realistic, dignified account of women's resistance to male domination, without minimizing the harm done by oppression."148

It is precisely this type of counternarrative that is foreclosed by the "unable to leave" and "viewed as property" particular social groups - a grave harm to immigrant survivors. In order to receive what may be life-saving asylum status, women must sacrifice their sense of strength and power, and perhaps even their identities. This requirement speaks volumes about our legal system and its view and treatment of women. Moreover, it sends a chilling message to survivors of domestic violence who are newcomers to the United States as well as to the rest of the world, one that will be addressed in Part IV.D below, that only certain types of women - those that are meek, docile, and powerless - are welcome in this country.

\section{Lawyering and Feminist Critiques}

\section{Challenges for Client-Centered and Ethical Advocacy}

As described in Part IV.B above, the inability of a survivor of domestic violence to convey a narrative or present an identity of empowerment is highly problematic from a psychological perspective. But it is damaging from a legal perspective as well, because permitting only a unitary and essentialized image of a battered woman in asylum law creates challenges for client-centered representation.

The goal of client-centered representation, the method of advocacy most frequently taught in law school clinical programs, is to move away from a paternalistic model of lawyering towards one which increases clients' control of and power in the attorney-client relationship. ${ }^{149}$ The lawyer's role is to provide information and counsel, while the client is given primary responsibility over decision-making in her case, largely based on the understanding that the client is best equipped to understand her life and needs and make determinations about the best course of action for herself and her

${ }^{146}$ M. Joan McDermott \& James Garofalo, When Advocacy for Domestic Violence Victims Backfires: Types and Sources of Victim Disempowerment, 10 Violence AGAINST WOMEN 1245, 1250 (2004).

147 Goodmark, supra note 131 , at 79.

148 Martha Chamallas, Introduction to Feminist Legal Theory 97 (2d ed. 2003).

${ }^{149}$ Katherine R. Kruse, Engaged Client-Centered Representation and the Moral Foundations of the Lawyer-Client Relationship, 39 HOFSTRA L. REV. 577, 585-86 (2010). 
family. ${ }^{150}$ The theory also teaches that every attempt should be made to understand and present both legal and factual scenarios from the client's point of view. ${ }^{151}$

Asylum law's restrictive and reductive narrative of a domestic violence survivor as a weak and helpless victim may prevent a lawyer from engaging in client-centered representation. In the client-centered lawyering model, an attorney is expected to lay out all the legal options to her client, including both potential risks and benefits of different approaches, and allow the client to decide on a course of action. ${ }^{152}$ Knowing that she must present a particular story and certain type of client to the adjudicator in order to prevail, a lawyer may understandably be tempted to convince a client to omit or minimize any stories in which the client is not presented as meek or docile, despite wishes of the client to the contrary. More problematically, a lawyer may not even present the option of telling the counterstory to her client, as it would preemptively be deemed a nonviable legal strategy.

Even if a lawyer does not knowingly minimize the role of her client, unconscious cognitive bias may affect the information sought and ultimately presented. For example, confirmation bias, which is the tendency to seek out or listen only to evidence consistent with one's views or preconceptions - and thereby ignore or dismiss evidence that contradicts those views - might cause a lawyer to focus only on aspects of a client's narrative that conform to the prevailing battered woman narrative. ${ }^{153}$ Thus, in adhering to stock stories,

${ }^{150}$ Katherine R. Kruse, Fortress in the Sand: The Plural Values of Client-Centered Representation, 12 Clinical L. REV. 369, 390 (2006).

151 This one-paragraph description is of course sorely inadequate, as much has been written about the theory of client-centered representation in a variety of legal areas. See, e.g., DAVID A. BINDER ET AL., LAWYERS AS COUNSElORS: A CLIENT-CENTERED APPROACH (3d ed. 2012) (examining many aspects of lawyering, including counseling, informationgathering, and decision-making, from a client-centered perspective); Robert D. Dinerstein, Client-Centered Counseling: Reappraisal and Refinement, 32 ARIZ. L. REV. 501 (1990) (assessing various models of client-centered counseling); Donald G. Gifford, The Synthesis of Legal Counseling and Negotiation Models: Preserving Client-Centered Advocacy in the Negotiation Context, 34 UCLA L. REV. 811 (1987) (discussing client-centered representation in the negotiation context); Dina Francesca Haynes, Client-Centered Human Rights Advocacy, 13 CLINICAL L. REV. 379 (2006) (addressing client-centered representation in the field of human rights); Kruse, supra note 149 (addressing the interplay between client-centered representation and ethics); Kruse, supra note 150, 370 71 (identifying client-centered representation as "one of the most influential doctrines in legal education today"); James E. Moliterno, A Golden Age of Civic Involvement: The Client Centered Disadvantage for Lawyers Acting as Public Officials, 50 WM. \& MARY L. REV. 1261 (2009) (discussing the relevance of client-centered representation for lawmakers and public officials); Laurie Shanks, Whose Story Is It Anyway?-Guiding Students to Client-Centered Interviewing Through Storytelling, 14 ClinICAL L. REV. 509 (2008) (explaining the challenges of persuasively telling a client's story).

152 See Kruse, supra note 150 , at 369.

${ }^{153}$ See generally Raymond S. Nickerson, Confirmation Bias: A Ubiquitous Phenomenon in Many Guises, 2 REV. GEN. Psychol. 175 (1998). 
advocates may consciously or unconsciously limit their client's voice, as in the process of "pick[ing] and choos[ing] from among the available facts to present a picture of what happened," certain facts are chosen for emphasis, the whole story may never be told, and ultimately, the whole person may be lost. 154

This concern is particularly pronounced in the area where domestic violence and asylum intersect. With respect to legal advocacy for women who have experienced domestic violence, as explained above, a lawyer's imposition of a particular narrative against her client's will may serve to replicate and perpetuate the imposition of power and control a survivor experienced in her abusive relationship. And in the context of asylum law, where the nature and history of the "largely male-oriented body of law" has conditioned lawyers to formulate women's cases "in ways which reflect the advocate's understanding of the law rather than the reality of the applicant's experiences," the inability of a female client to tell her true story impacts not only the survivor herself but the status of women in the immigration legal system as a whole. ${ }^{155}$ Strict adherence to the Matter of $L-R$ - and Matter of $A$ $R-C-G$ - particular social group formulations may therefore damage the relationship between a lawyer and her client, inhibit open and honest communication, and may ultimately even adversely impact the outcome of a legal case (or the integrity of the legal system as a whole) -all things that client-centered advocacy seeks to prevent.

Moreover, in the most extreme cases, an attorney's unwavering commitment to utilizing the groups articulated in Matter of $L-R$ - and Matter of $A-R-C-G$ - may lead to ethical lapses. Rule 1.2 of the Model Rules of Professional Conduct states that "a lawyer shall abide by a client's decisions concerning the objectives of representation and ... shall consult with the client as to the means by which they are to be pursued."156 Similarly, Rule 1.4 requires a lawyer to: "reasonably consult with the client about the means by which the client's objectives are to be accomplished;... [and] explain a matter to the extent reasonably necessary to permit the client to make informed decisions regarding the representation." 157 In attempting to strictly adhere to the Matter of $L-R$ - and Matter of $A-R-C-G$ - formulations, an attorney may be tempted not to consult with her client about the narrative advanced in the case, may not fully explain all potential legal avenues and options to her client, or may disregard a client's wishes about the story she seeks to tell. Any of these actions, resulting from the limitations imposed by the existing particular social groups, may not only be ill-advised as not client-centered, but may also constitute a violation of an attorney's ethical obligations.

154 Delgado, supra note 142 , at 2421.

${ }^{155}$ Nancy Kelly, Gender-Related Persecution: Assessing the Asylum Claims of Women, 26 CORNELL INT'L L.J. 625, 629 (1993).

156 MOdel Rules OF PROF’L CONDUCT r. 1.2(a) (AM. BAR ASS'N 2014).

${ }^{157}$ Id. r. 1.4 (a)-(b). 


\section{Victim Blaming}

The term "victim-blaming" was coined by Dr. William Ryan, who described the phenomenon in the context of racial discrimination, explaining that whites justified inequality and social injustice against blacks by finding defects in their African-American victims. ${ }^{158}$ The practice of blaming a victim for harms that befall her is also widespread in the area of violence against women. ${ }^{159}$ In the domestic violence context, the question of "why didn't she just leave?" is frequently used to shift focus from the abuser's behavior and fault onto the victim for not taking steps to avoid his violence. ${ }^{160}$ Debilitating to the women who have suffered abuse, victim-blaming is also a means for allowing violent behavior to continue. ${ }^{161}$ As Walker argues, "[b]y perpetuating the belief that it is rational to blame the victim for her abuse, we ultimately excuse men for the crime."162

Victim-blaming is perpetuated by the $L-R$ - and $A-R-C-G$ - particular social group formulation because a natural question when hearing that a battered woman is unable to leave a relationship is, "Why not?" Perhaps the victim did not try hard enough. Or perhaps the abuse wasn't so bad after all or she would

158 See generally William RyAn, BLAMING THE Victim (1971) (discussing the phenomenon of victim-blaming).

${ }^{159}$ See generally Francis X. Shen, How We Still Fail Rape Victims: Reflecting on Responsibility and Legal Reform, 22 COLUM. J. GENDER \& L. 1 (2011) (discussing victimblaming in the context of sexual assault); Jerry von Talge, Victimization Dynamics: The Psycho-Social and Legal Implications of Family Violence Directed Toward Women and the Impact on Child Witnesses, 27 W. ST. U. L. REV. 111, 131 (2000) (noting that a "second dimension of the multiple victimization of women is societal blame").

160 See generally Ola W. BARNETt \& ALYCE D. LAViolette, It COUld HaPPEN to ANYONE: WHY BATTERED WOMEN STAY (1993) (discussing the cognitive and social reasons why battered women stay with their abusers); WHY DOESN'T SHE JUST LEAVE? (Heather Stark \& Emilee Watturs eds., 2008) (explaining recent research and real women's stories to explore why women remain with their abusers); Sarah M. Buel, Fifty Obstacles to Leaving, a.k.a., Why Abuse Victims Stay, COLO. LAw., Oct. 1999, at 19 (delineating fifty reasons why abuse victims stay with their abusers). This phenomenon was highlighted recently after the public release of a video of professional football player Ray Rice physically abusing his wife led him to be suspended indefinitely from the NFL. Rheana Murray, After Ray Rice Video, Women Explain \#WhyIStayed, ABC NEws (Sept. 9, 2014), $\mathrm{http} / / /$ abcnews.go.com/US/ray-rice-video-women-sound-off-whyistayed/story?id=25374313 [https://perma.cc/8ECB-56TK]. When his wife came to his defense, many questioned her decision to remain with him, prompting the proliferation of the Twitter hashtag \#WhyIStayed through which women explained the complex reasons that survivors of domestic violence chose to remain with abusive partners. Id.

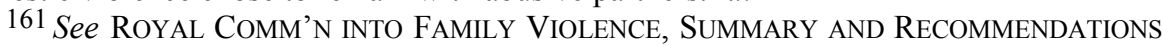
16 (Mar. 2016), http://files.rcfv.com.au/Reports/RCFV_Full_Report_Interactive.pdf [https://perma.cc/X492-5SVB] ("Community attitudes that misconstrue or condone family violence have powerful impacts: they compound the shame that victims feel and dissuade them from making disclosures and seeking assistance, and they give licence [sic] to perpetrators to continue their abuse.").

162 WALKER, supra note 26 , at 15. 
have tried harder to escape it. Even if onus of action in "unable to leave" is placed on the abuser, i.e., that he did not allow her to leave as opposed to her being unable to leave, questions about the existence of personal failings in the victim that prevented her from taking the necessary steps to protect herself remain.

In Matter of $A-R-C-G-$, the BIA noted that "a married woman's inability to leave the relationship may be informed by societal expectations about gender and subordination, as well as legal constraints regarding divorce and separation." 163 In Ana's case, a multitude of factors prevented her from leaving her abusive husband: absence of economic resources, feelings of isolation and lack of support from her family members, and his threats to bar her from seeing their daughter if she left. His connections to law enforcement were also a significant barrier to her ability to break free and are likely also evidence of the government's unwillingness to protect her from harm. However, given the complexity and nuance involved in these issues, it remains to be seen what effect the dicta in Matter of $A-R-C-G$ - will have and whether or not courts will actually consider such factors when making determinations about survivors' decisions and actions.

\section{Separation Violence}

Framing the problem of domestic violence around a woman's inability to leave also raises concerns related to the theory of separation violence, or separation assault. Conceived by Professor Martha Mahoney, the term describes the escalation of violence and incidence of higher rates of physical assault towards women following attempts to break free from violent relationships or otherwise assert their independence from their abusers. ${ }^{164}$ If, as is widely understood, domestic violence is ultimately about an abuser's need to exert power and control, the notion of separation violence is quite logical, as a woman's efforts to leave threaten the batterer's exercise of that power and control. Empirical research thus establishes that a woman is at greatest risk of injury or death when she leaves or attempts to leave an abusive relationship because heightened violence is a means for a batterer to regain or reassert control after his partner's demonstration of agency. ${ }^{165}$

${ }^{163}$ In re A-R-C-G-, 26 I. \& N. Dec. 388, 393 (B.I.A. 2014).

${ }^{164}$ Mahoney, supra note 140, at 64.

165 See generally Barbara J. Hart, The Legal Road to Freedom, in BATTERING AND FAmily Therapy: A Feminist PersPective 13 (Marsali Hansen \& Michèle Harway eds., 1993) (citing a variety of studies on separation violence); Margo Wilson \& Martin Daly, Spousal Homicide Risk and Estrangement, 8 ViolenCE \& VicTiMs 3, 8 (1993) ("[W]ives are much more likely to be slain by their husbands when separated from them than when co-residing."). A report recently released by the Dallas Domestic Violence Taskforce and the Institute for Urban Policy Research at the University of Texas at Dallas highlights the significance of separation violence in just one community. See generally DENISE PAQUETTE Boots \& Timothy Bray, Dall. DOMESTIC Violence TASKForce \& InST. FOR URbaN 
The "unable to leave" formulation effectively penalizes a battered woman who attempts to break free from domestic violence. If she was able to leave (either temporarily or permanently in her escape to the United States) it may reasonably be argued that these efforts to flee render her ineligible for membership in the stated particular social group. Although the "unable to leave" particular social group formulation is typically understood as having a silent parenthetical of ("until now") attached to the end, ${ }^{166}$ it is not always safe to rely upon this legal fiction. An immigration judge in an unpublished case highlighted this point, and demonstrated the inconsistency and confusion surrounding the "unable to leave" group, when denying the asylum claim of a battered woman because "the applicant's status in the relationship was not immutable because she 'did eventually leave [her abuser]' to flee to the United States, which "terminat[ed] the relationship.""167

An act of separation that may jeopardize a battered woman's legal status is also precisely what may exacerbate her risk of serious harm. As experts have noted:

By leaving the relationship, the battered woman is engaging in the ultimate challenge to her abuser's power, authority, and control. ... [T] he abuser now knows that she is capable of leaving him, and he escalates his abuse in order to punish her for her challenge to his authority and to ensure that such a challenge does not happen again. ${ }^{168}$

Thus, ironically, acting in a manner that runs counter to the "unable to leave" narrative is what puts a woman at the greatest risk of harm-thus meriting asylum protection the most - but this behavior may be the thing that causes her to be denied protection at this critical time.

Policy Research at the Univ. of Tex. at Dall., AnNual Summary Report: 20142015 (2015), http://www.neighborhoodindicators.org/sites/default/files/publications/Dallas \%20Domestic\%20Violence\%20Taskforce\%20Report\%20-\%20Final\%20-\%20Copy.pdf [https://perma.cc/GVB4-UM68]. Of the thirty-four intimate partner violence fatalities that occurred between 2009 and 2011 in Dallas, "[f]ive ... victims were killed immediately after threatening to break up with the perpetrator just before the homicide, 4 victims has [sic] just ended their relationship with the offender immediately prior to the homicide, and 6 of the relationships ended some time prior to the homicide event." Id. at 26 . In total, $44 \%$ of the homicides in Dallas during the three-year period were attributable to separation violence. $I d$.

166 This is the only logical way to interpret the particular social group definition because if a woman had truly been unable to leave the relationship, she would not be in the United States seeking asylum.

${ }^{167}$ Bookey, supra note 6, at 140 (alterations in original) (quoting the immigration judge).

${ }_{168}$ Marisa Silenzi Cianciarulo \& Claudia David, Pulling the Trigger: Separation Violence as a Basis for Refugee Protection for Battered Women, 59 AM. U. L. REV. 337, 342 (2009). 


\section{The "Worthiness" Problem}

A study described in Evan Stark's seminal book, Coercive Control, starkly reveals the dangers of constructing and relying on essentialized portraits of battered women. ${ }^{169}$ The study examined the admission logs of a California domestic violence shelter and found that women who were deemed "worthy" of entry into the shelter typically fit the stereotypical image of the pitiable, passive, and "morally pure" victim. ${ }^{170}$ Meanwhile, women who were not visibly injured, or who demonstrated strength, agency, or resilience in the face of abuse, were turned away. ${ }^{171}$ As one log entry noted about an "unsuitable" service-seeker (in a depiction that could easily have been used to describe Ana): "she is an extremely young woman with 'ruff attitude' - if he hits me I always hit him back." 172 Women who appeared too agitated or confused, seemed unlikable or strange, or did not otherwise fit the stereotypical victim profile, were considered inappropriate for admission. ${ }^{173}$ Meanwhile, those who were considered "a very classical case and nice" readily received shelter and protection. ${ }^{174}$

These images and narratives of "undesirability and unworthiness" contrasted with those of "worthiness and blamelessness" also pervade immigration law, ${ }^{175}$ making this issue particularly salient in an area that examines the intersection of gender-based violence and asylum. In the law, in the media, and in public perception, there exist images of archetypal "good" immigrants who deserve their place in American society, and conversely, "bad" immigrants who should be denied admission or expelled from the United States ${ }^{176}$ And while survivors of domestic violence are likely to land in

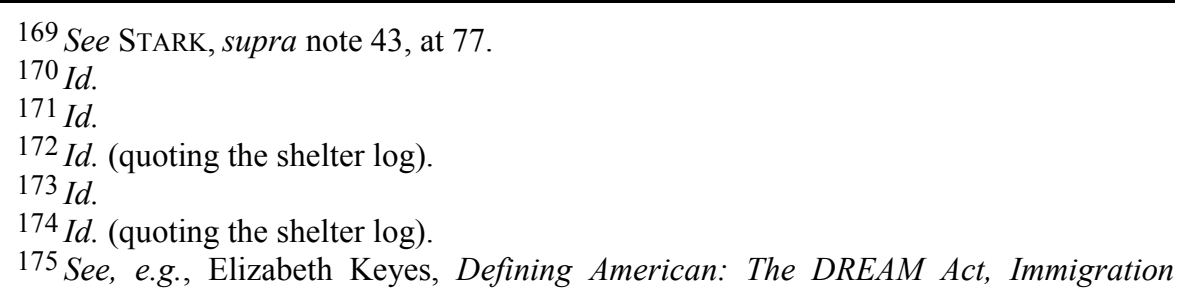
Reform and Citizenship, 14 NEv. L.J. 101, 104 (2013). See generally, e.g., Elizabeth Keyes, Beyond Saints and Sinners: Discretion and the Need for New Narratives in the U.S. Immigration System, 26 GEO. IMMIGR. L.J. 207 (2012) (examining the polarizing narratives of "good" and "bad" immigrants); Harold Hongju Koh, Who Are the Archetypal "Good" Aliens?, 88 AM. SOC'Y INT'L L. PROC. 450 (1994) (discussing causes and consequences of labeling "good" and "bad" immigrants).

176 See, e.g., Alexia Fernández Campbell, The Problem with Only Letting in the 'Good' Immigrants, ATLANTIC (Oct. 11, 2016), http://www.theatlantic.com/business/archive/2016/ 10/immigration-winners-and-losers/503435/ [https://perma.cc/Q3V3-F6GS]; The Daily Show with John Stewart: The Two Faces of Illegal Immigration (Comedy Central television broadcast Oct. 10, 2013), http://thedailyshow.cc.com/videos/u60haq/the-twofaces-of-illegal-immigration [https://perma.cc/YQ4U-J9AL] (video clip profiling the city manager of Dayton, Ohio who views the influx of immigrants as a positive thing for the economy as well as a documentary film maker and conservative commentator, who notes that, while there are some immigrants here to better their lives, most are dangerous and 
the former category, this may only be because the concept "of the "good female alien' [is] rooted in notions of passivity and helplessness." 177

Professor Stacy Brustin explains that many of the existing immigration protections for battered women-enshrined in the INA of 1990 and the VAWA - exist because the "policy and public debate center[ed] around an image of immigrant women as deserving of legalization because they are frightened, helpless victims." 178 The Matter of $L-R$ - and Matter of $A-R-C-G$ particular social group formulations further entrench this image of the powerless victim and thereby serve to perpetuate the dichotomy of good and bad immigrant. Matter of $L-R$ - and Matter of $A-R-C-G$ - teach that a "good" battered woman asylum seeker is a piece of property who lacks the agency to leave her pitiable situation. She, unlike a woman who resists and fights back against the violence she faces, is deemed worthy of admission to, and protection in, the United States.

\section{PROPOSED FIXES}

Although reliance on particular social group formulations that perpetuate the victimization of battered women is deeply problematic for the many reasons articulated above, fortunately, several alternatives to the currently utilized frameworks exist.

\section{A. Issuance of a Final Rule Governing Domestic Violence Asylum Claims}

As explained in Part III, on December 7, 2000, after the BIA's initial denial in Matter of $R-A$-, the DOJ issued a proposed rule whose stated aim was to "aid in the assessment of claims made by applicants who have suffered or fear domestic violence." ${ }^{179}$ In an effort to bring clarity to domestic violence-

detrimental to our communities); ISD Editorial Board, Editorial, Child Immigrants Deserve U.S. Protection, IOwA ST. DAILY (July 30, 2014), http://www.iowastatedaily.com/opinion/e ditorials/article_5ff62ae8-142e-11e4-b59d-0019bb2963f4.html [https://perma.cc/M5KK6DZM] (asserting that, while they may have entered the country unlawfully, unaccompanied immigrant children crossing the border, many fleeing violence and poverty, should be allowed to stay in the United States); Dave Seminara, Legalizing Illegal Immigrants a Bad Idea, CHI. TRIB. (Feb. 8, 2013), http://articles.chicagotribune.com/201302-08/opinion/ct-perspec-0208-immigration-20130208 1 illegal-immigrants-legal-statusguest-worker [https://perma.cc/MY9T-8GJN] (explaining that, while he supports the DREAM Act, which would give permanent residency to certain immigrants who arrived in the Untied States as minors, the author opposes a pathway to citizenship for all unlawfully present immigrants because it would "vindicate those who broke the law," increase identity fraud, and would not cause those dangerous people living in the shadows to come forward).

${ }^{177}$ Brustin, supra note 14 , at 455 .

178 Id. at 456.

${ }^{179}$ Asylum and Withholding Definitions, 65 Fed. Reg. 76588 (proposed Dec. 7, 2000) (to be codified at 8 C.F.R. $\S 208.13$ ). 
based asylum claims, the proposed rule first reiterates and confirms that "gender can form the basis of a particular social group" and that survivors of domestic violence are entitled to asylum in the United States. 180 The proposed rule also deliberately "does not specify how a claim of persecution based on domestic violence should be fashioned - in particular, it does not set forth what the precise characteristics of the particular social group might be" because the DOJ recognized that crafting a particular social group is a factspecific endeavor and groups will likely "vary depending upon the social context" of the applicant's country. ${ }^{181}$ It instead lays out "generally applicable principles" and factors to consider when adjudicating domestic violence asylum claims. ${ }^{182}$

Decision-making in Matter of $R$ - $A$ - was stalled for years in anticipation of finalization of this rule, ${ }^{183}$ and today, many administrations and seventeen years later, it remains in proposed form. The lengthy delay and absence of final regulations have been a significant cause of the confusion and uncertainty in domestic violence asylum law. The lack of direction from the DOJ likely also contributed to courts' reluctance to render published precedent decisions on the subject. And while Matter of $A-R-C-G-$ has created some certainty, unlike the proposed rule, it limits viable claims to only those that fit a narrow category articulated in its accepted particular social group.

Finalizing the proposed rule at long last would not only bring additional certainty to this area of the law, but also provide guidance to both advocates and decision-makers, who would then have the freedom to proceed with their own analyses within the general framework of the DOJ policy. And because the proposed regulations refrain from proposing particular social groups, all of the participants in the system would be free to deviate from the existing Matter of $L-R$ - and Matter of $A-R-C-G$ - frameworks that further the narrative of the helpless, meek, and submissive victim in favor of case-specific and factspecific groups that recognize a variety of responses to domestic violence.

\section{B. Advancing Alternative, Non-Essentializing, Particular Social Groups}

Although issuance of final regulations by the DOJ would undoubtedly be a significant milestone, there is currently no indication of when the rule might be finalized, and the existing delay certainly has not led to much optimism about its imminent release. ${ }^{184}$ And because the Department declined to propose specific social groups for domestic violence cases, it is not certain that

${ }^{180} \mathrm{Id}$.
${ }^{181} \mathrm{Id}$. at 76589.
$182 \mathrm{Id}$.
${ }^{183}$ See Matter of $R-A-$-, supra note 90.

184 See Bookey, supra note 6, at 148 ("The U.S. government has stated that regulations are 'being worked on' by DHS and DOJ. If the last twelve years are any indication, little confidence can be placed in such pronouncements." (footnote omitted) (quoting The Regulatory Plan, 74 Fed. Reg. 64137, 64221 (Dec. 7, 2009))). 
issuance of final regulations would solve the problems raised by this Article. Even if the rule is finalized, attorneys and judges may continue to rely on the Matter of $L-R$ - and Matter of $A-R-C-G$ - frameworks due to inertia or simply because a better alternative is not readily apparent. Therefore, what follows below are examples of potential particular social groups that could be used in lieu of the existing Matter of $L-R$ - and Matter of $A-R-C-G$ - formulations. These proposed groups are not intended to be an exhaustive list, as the goal of this Article is not to create additional pigeonholes or limitations; they are simply suggestions that advocates may draw upon as examples of alternative groups. All of the proposed groups depart from the existing narrative of the helpless, docile, and submissive battered woman and instead advance a group definition that allows for survivors of domestic violence to demonstrate strength, self-reliance, and empowerment.

\section{Women as a Particular Social Group}

The simplest articulation of a particular social group would be "women" from the applicant's home country, or perhaps the applicant's village, city, town, or geographic region. Such an approach is supported by the United Nations, ${ }^{185}$ the scholarly community, ${ }^{186}$ and existing federal case law. ${ }^{187}$ However, recognizing that while viable, "women" as a particular social group may not readily be accepted by decision-makers, the group could be narrowed

185 U.N. High Comm'r for Refugees, Guidelines on International Protection: GenderRelated Persecution Within the Context of Article 1A(2) of the 1951 Convention and/or Its 1967 Protocol Relating to the Status of Refugees, 9 30, U.N. Doc. HCR/GIP/02/01 (May 7, 2002) ("It follows that sex can properly be within the ambit of the social group category, with women being a clear example of a social subset defined by innate and immutable characteristics, and who are frequently treated differently than men. Their characteristics also identify them as a group in society, subjecting them to different treatment and standards in some countries." (footnote omitted)).

186 See generally Bethany Lobo, Women as a Particular Social Group: A Comparative Assessment of Gender Asylum Claims in the United States and United Kingdom, 26 GEo. IMMIGR. L.J. 361 (2012) (comparing the approach of the United States with that of the United Kingdom and noting that the U.K. House of Lords has recognized asylum claims based on the particular social group of "women" in their home state); David L. Neal, Women as a Social Group: Recognizing Sex-Based Persecution as Grounds for Asylum, 20 Colum. HuM. RTS. L. REV. 203 (1988) (demonstrating domestic and international legal support for a particular social group of "women").

187 See Perdomo v. Holder, 611 F.3d 662, 667 (9th Cir. 2010) (“Thus, we clearly acknowledged that women in a particular country, regardless of ethnicity or clan membership, could form a particular social group."); Hassan v. Gonzales, 484 F.3d 513, 518 (8th Cir. 2007) (finding "Somali females" to be a cognizable particular social group); Mohammed v. Gonzales, 400 F.3d 785, 797 (9th Cir. 2005) ("Although we have not previously expressly recognized females as a social group, the recognition that girls or women of a particular clan or nationality (or even in some circumstances females in general) may constitute a social group is simply a logical application of our law." (footnote omitted)). 
by the inclusion of one of many limiting characteristics. Descriptors and limitations based on age, relationship status, opposition to abuse, or family, clan, or tribal membership could serve to further delineate membership.

\section{Women Who Resist Domestic Violence but Are Unable to Leave Their Relationship}

A second potential re-conception of the "unable to leave" particular social group is not to do away with it altogether, but to simply modify it to better reflect the reality of many women's responses to domestic abuse. A particular social group of "women who resist domestic violence but are unable to leave the relationship" would allow for applicants to articulate and reclaim an aspect of their stories and present a counternarrative that is not premised on helplessness and passivity to violence.

Such a social group would surely be viable, as the "unable to leave" portion has already been deemed to be in compliance with existing standards and requirements for particular social groups. ${ }^{188}$ The additional characteristics "women" and "resist[ing] domestic violence" both also survive scrutiny. Being a woman is inarguably an immutable characteristic and women are both recognized as a discrete class of persons and seen as a distinct group in all societies. Similarly, resisting violence is immutable as it is surely so fundamental to a woman's identity or conscience - not to mention safety and bodily integrity - that she should not be required to change her behavior. Women who fight back against domestic abuse are also a sufficiently particular group, although advocates may be able to further refine what form the resistance took and potentially alter the group definition accordingly. Lastly, if abused spouses who are unable to leave survive a social distinction analysis, it is logical that those who resist but are subsequently unable to leave would also be sufficiently socially distinct.

\section{Women Who Assert Independence from Abusive Partners or Women Who Challenge Male Domination}

Another possible particular social group that could be utilized by survivors of domestic violence seeking asylum in the United States is "women who assert independence from abusive partners" or "women who challenge male domination." While not overtly relying on a feminist or anti-violence political opinion, these groups implicate that alternative ground of protection under asylum law. And like the group above, these formulations present a strong image of a battered woman who is affirmatively acting to resist abuse.

Because these groups rely heavily on the more clear-cut political opinion ground of asylum protection, and because the component of resistance makes them comparable to the particular social group long-accepted as precedent in

188 See Bookey, supra note 6, at 135 n.114. 
Matter of Kasinga ${ }^{189}$ they too are viable under the existing particular social group definition and requirements. As discussed above, gender is immutable, and the challenge to, or assertion of, independence from abuse is certainly fundamental to one's identity and conscience. The terms used in the group are specific, although again, fact-finding and investigation could certainly make them more specific on a case-by-case basis, and such defiance of family violence will often be unique enough in a particular culture that those who undertake such brave acts are understood to constitute a discrete group.

\section{Women Who are Married to (or in Relationships with) Abusive Men}

Framing a particular social group not around victims of violence but around the perpetrators themselves is yet another possibility. A group of "women who are married to (or in relationships with) abusive men" puts the onus precisely where it should be-on the batterers and violent men themselves. Although DHS claimed that the particular social group "abused women" was circular in its 2009 brief, 190 this group is distinguishable, as it focuses not solely on the abuse suffered, but on the effect both the relationship and the abusive character of the partner have on the likelihood of persecution. And as with the groups above, a particular social group defined by gender and familial relationship arguably satisfies the requirements of immutability, visibility, and particularity.

\section{Women Who Have Fled an Abusive Relationship}

Finally, another potential particular social group is "women who have fled an abusive relationship." This articulation is appealing because it recognizes the significant role that separation violence plays in abusive relationships; as discussed in Part IV.C.3, the time after a woman leaves her batterer is statistically the most lethal and therefore arguably most meriting of the safe harbor of asylum protection. This group also departs from a view of women as impotent and incapable non-actors, as the focus is on a woman's active response of departing and protecting herself from violence.

However, this group is also not without its challenges. One major drawback relates to nexus, as a woman can only face future harm on account of her membership in this group. Because the group cannot encompass past persecution, an applicant would have to focus solely on the harm that would befall her in the future and therefore forfeit her ability to benefit from the presumption of future persecution that attaches when past persecution is

${ }^{189}$ In re Kasinga, 21 I. \& N. Dec. 357, 358 (B.I.A. 1996) (“[T]he applicant is a member of a social group consisting of young women of the Tchamba-Kunsuntu Tribe [of northern Togo] who have not had [female genital mutilation], as practiced by that tribe, and who oppose the practice." (emphasis added)).

${ }^{190}$ DHS 2009 Brief, supra note 9 , at 10-11. 
established. ${ }^{191}$ But if the facts of a specific case do not make this a liability, for example, if a claim for past persecution is weak or difficult to prove, a group focused on a woman's escape from violence would otherwise qualify as a valid particular social group under existing asylum law. The act of fleeing is immutable and the terms in the group - gender, abuse, and flight — are readily definable, thereby making the group delineable. The absence of these spouses from their homes and communities would also make them distinct as a group.

Of course, it is not sufficient for these five alternative particular social groups, or any others that creative lawyers posit, to exist in theory or solely in the pages of law journals. In order to create public and judicial awareness and acceptance of Professor Delgado's "counterstories"- those that empower, "challenge the received wisdom" and "show[] us that there are possibilities for life other than the ones we live"-advocates must actually advance these claims in their cases. ${ }^{192}$

As indicated above, in its proposed regulations, the DOJ declined to articulate a particular social group for domestic violence claims, noting that group definitions are fact-specific and "likely will vary depending upon the social context in [the] country." 193 The agency stated that it was "ill-advised to try to establish a universal model for persecution claims based on domestic violence" and that a "case-by-case adjudication" was more appropriate for such claims. ${ }^{194}$ However, in reality, advocates often do not deviate from the accepted particular social groups in domestic violence claims, relying largely on - and perhaps even attempting to shoehorn their clients into- the Matter of $L-R$ - and now codified Matter of A-R-C-G- formulations. This is of course understandable, as attorneys are generally a risk-averse group and the potentially life-threatening consequences of losing an asylum claim make it a particularly unsuitable area for impact litigation. However, the fact remains that alternative particular social groups are available and viable, and unless advocates begin advancing such claims, the law will never progress beyond the current essentializing groups.

\section{CONCLUSION}

The law has made great strides in protecting women who seek refuge in the United States from domestic violence, but there is still a long way to go before such cases are considered coequal to more traditional asylum claims. Historically, asylum law in the United States has been a mechanism to support and protect those who fight against injustice and bravely rise up against the

${ }^{191}$ An applicant who has been found to have established past persecution shall also be presumed to have a well-founded fear of persecution (or that his or her life or freedom would be threatened) on the basis of the original claim. See 8 C.F.R. § 208.13(a)(1) (2016).

192 Delgado, supra note 142, at 2414.

193 Asylum and Withholding Definitions, 65 Fed. Reg. 76588, 76589 (proposed Dec. 7, 2000) (to be codified at 8 C.F.R. $§ 208.13$ ).

${ }^{194}$ Id. 
greater power of the state. ${ }^{195}$ But as Professor Marisa Silenzi Cianciarulo eloquently states, "[d]omestic violence, particularly in countries that are unable or unwilling to protect victims, is the manifestation of a state belief in male dominance." 196 Viewed through this lens, battered women are not so different from the revolutionaries, freedom fighters, and political activists who came before them. They are abused by, but also often rise up against, men who have had the benefit of years of systematic privileges: the reinforcement of male privilege in law, culture, and society; the lack of sufficient infrastructures to adequately address domestic abuse; the reluctance of judicial actors to believe the stories of victims of family violence; and many more.

The first step in recognizing battered women as the fighters and survivors they unquestionably are is to reframe the asylum narrative for those seeking protection in the United States from domestic violence. Advancing particular social groups that move away from depictions of women as helpless, dependent, and impotent victims and instead accepting stories of power and agency will be a significant step in bringing much needed gender equity into asylum law.

195 See Matthew E. Price, Politics or Humanitarianism? Recovering the Political Roots of Asylum, 19 GEO. IMMIGR. L.J. 277, 282 (2004) (explaining that the origins of asylum law have largely centered around protected citizens rising up against their regimes).

196 Cianciarulo \& David, supra note 168, at 369 (citing In re R-A-, 221 I. \& N. Dec. 906, 939 (B.I.A. 1999) (Member Guendelsberger, dissenting)). 
